\title{
Structural and functional improvement of snipped sciatic nerve after allograft injection of Schwann cells into fibrin scaffold
}

\author{
Salati $\mathbf{A}^{1,2}$, Aboutaleb Kadkhodaeian $\mathbf{H}^{3,4}$ \\ 1. Assistant Professor of Tissue Engineering and Applied Cell Sciences, Nervous System Stem Cell Research Center, \\ Semnan University of Medical Sciences, Semnan, Iran. ORCID ID: 0000-0002-6840-1527 \\ 2. Assistant Professor of Tissue Engineering and Applied Cell Sciences, Department of Tissue Engineering and Applied Cell \\ Sciences, Faculty of Medicine, Semnan University of Medical Sciences, Semnan, Iran. \\ 3. Assistant Professor of Anatomy Sciences, Nervous System Stem Cell Research Center, Semnan University of Medical \\ Sciences, Semnan, Iran. \\ 4. Assistant Professor of Anatomy Sciences, Department of Anatomical Sciences, Faculty of Medicine, Semnan University of \\ Medical Sciences, Semnan, Iran (Corresponding author), Tel: +98-233365428, Email: habootaleb92@gmail.com, ORCID \\ ID: 0000-0002-9736-9722
}

\begin{abstract}
Background and Aim: Peripheral nerve injuries are among the most common types of injuries of the nervous system and are regarded as the main cause of disability. These injuries can lead to disorders in muscles movement and normal sense, and also painful neuropathy. Tissue engineering and stem cells therapy are among the treatment methods for these disorders. In this study we assessed sciatic nerve restoration through a silicone tube containing a fibrin scaffold filled with Schwann cells and citicoline by using electromyography and histological methods.
\end{abstract}

Materials and Methods: 50 adult male Wistar rats were randomly divided into five groups. 1. Silicon tube. 2. Silicon tube with fibrin gel. 3. Silicon tube with Schwann cells. 4. Silicone tube with citicoline. 5. Silicon tube with Schwann cells \& citicholine. The left sciatic nerve was cut and a $10 \mathrm{~mm}$ gap was created. A silicon tube was placed between the two cut ends of the nerve, as a guide channel. Allografted Schwann cells and citicoline were injected into the guide channel.

Results: The third and fifth groups were significantly different from other groups in regard to the amplitudes of the waves $(\mathrm{P}<0.05)$. Also, we found significant decreases in the latency of the waves recorded in the $1^{\text {st }}$ to $4^{\text {th }}$ groups $(\mathrm{P}<0.05)$. There was a significant difference between the third and fifth groups in the results of histological examination $(\mathrm{P}<0.05)$.

Conclusions: Increased amplitude in the third and fifth groups indicated better restoration of the nerve in these groups. Also reduced latency in the $1^{\text {st }}$ to $4^{\text {th }}$ groups was indicative of regeneration of the sciatic nerve. Histologic results revealed increased number of recovered axons in the fifth group which was indicative of the better outcome of the combination therapy.

Keywords: Schwann cell, Fibrin scaffold, Citicholine, Silicone tube, Electromyography, Sciatic nerve

Received: Jan 14, 2019 Accepted: June 12, 2019

How to cite the article: Salati A, Aboutaleb Kadkhodaeian H. Structural and functional improvement of snipped sciatic nerve after allograft injection of Schwann cells into fibrin scaffold. SJKU 2019;24(3):67-84. 


\section{بهبود ساختار و عملكرد عصب سياتيك قطع شده بعد از تزريق آلوكرافت سلولهاى شوان به درون داربست فيبرينى}

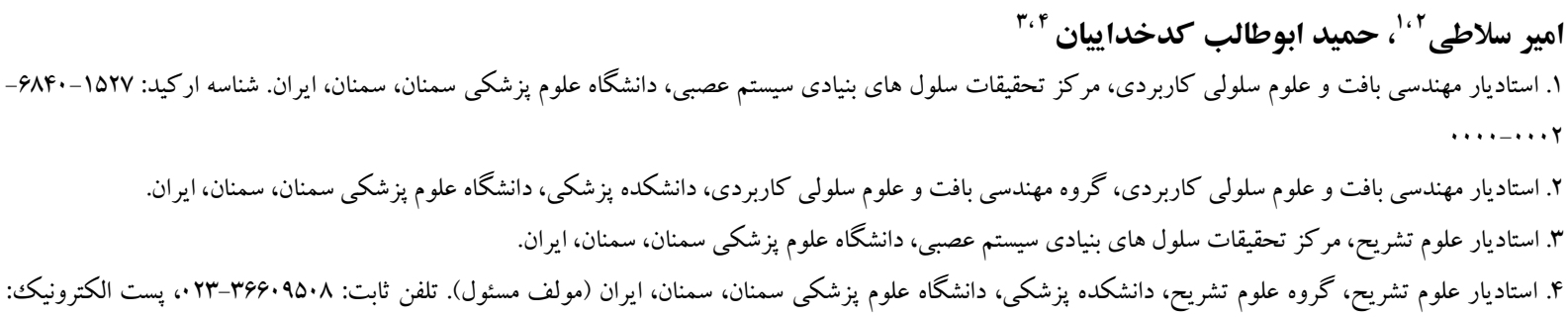
........r-qVrq_qVrr habootaleb92@gmail.com

جكيده

زمينه و هدف: صدمات اعصاب محيطى جز شايعترين آسيبهاى سيستم عصبى هستند و بزر گترين علـت نـاتوانى بـه شـمار مسى آيند. اين آسيب ها موجب اختلال در توانايى حر كات عضلات، حس طبيعى و نورويـاتى دردنـاكك مسىـود. يكى از روشهـاى درمانى در اين موارد استفاده از مهندسى بافت و سلول درمانى است. در اين تحقيق ترميم عصب سياتيك از طريـق لوله سـيليكونى حاوى داربست فيبرينى بر شده با سلولهاى شوان و داروى سيتى كولين و با استفاده از الكتروميـو خر افى و روشهـاى بـافتى مـورد بررسى قرار كرفته است.

روش بروسى: •ه سر رت نر نزاد ويستار به طور تصادفى به ينج گروه تقسيم شدند. () لوله سيليكون Y) لوله سـيليكون بـه همـراه زل فيبرين ץ) لوله سيليكون به همر اه سلولهاى شوان F) لوله سيليكون به همر اه سيتى كولين ه) لوله سيليكون به همـراه سـلولهـاى شوان و سيتى كولين. عصب سياتيك جِّ به اندازه • ا ميلى متر قطع و به عنوان كانال براى ترميم فاصـله ايجـاد شـده اسـتفاده شـد. سلول هاى شوان آلو گرافت كشت داده شده و داروى سيتى كولين به درون لوله تزريق شدند. يافته ها: دامنه موج الكتريكى ثبت شده در گروه سوم و ينجم تفاوت معنى دارى با ساير گروهها دارد (ه •/P>•P). همجنسين تـاخير در هدايت موج الكتريكى ثبت شده در گروههاى يكى تا جهار كاهش معنى دارى را نشان مىدهد در بررسى بافتى بين گحروههـاى سوم تا بنجم تفاوت معنى دارى وجود دارد (ه •/P> (P). نتيجه كيرى: افزايش دامنه موج در گروههاى سوم و بنجم بيانكر ترميم بهتر عصب در اين گرووه هـا مسىباشـد. كـاهش تـاخير در هدايت موج الكتريكى در گروههاى يكك تا جهار نيز نشان دهنده تر ميم عصب مىباشد. همجنين افزايش تعداد اكسونهاى ترميم شده در كرووه ينجم نشان دهنده نتيجه بهتر درمان تر كيبى است. كليد وازه ها: سلول شوان، داربست فيبرينى، سيتى كولين، لوله سيليكون، الكتروميو گر افى، عصب سياتيك

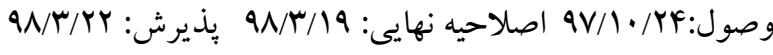


كه مخروط رشد را به سمت عضلات هدف حمايت و راهنمايى

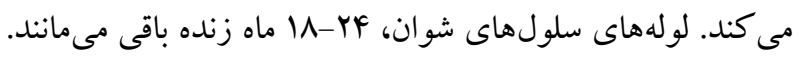
درصورتى كه اكسون به اندام هدف خود نرسد اين لوله ها لهان

$$
\text { تخريب و از بين مىروند (ه). }
$$

در حال حاضر اتو گرافت عصبى، استاندارد طلايى براى ضايعات

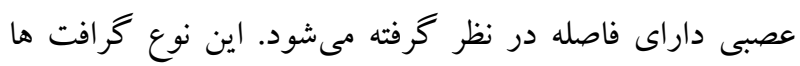

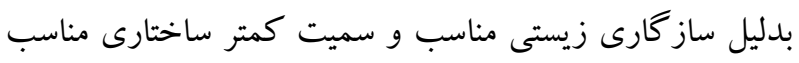

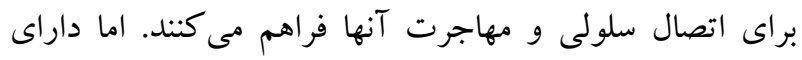
محدوديتهايى هستند از جمله اين كه موجب كاهش عملكرد، تشكيل نوروما در محل بيوند، و انجام جراحى هاى متعدد مى شود.

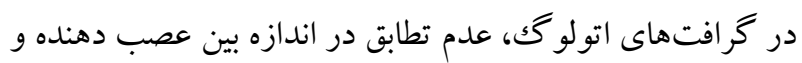

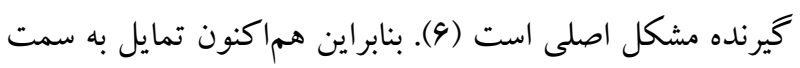

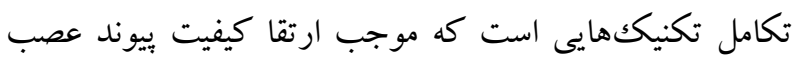

براى جايخزينى اتو گر افتها جهت تـرميم عصب محيطى، طيف

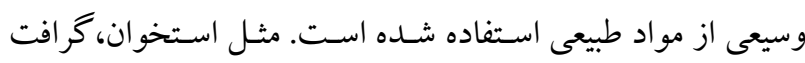

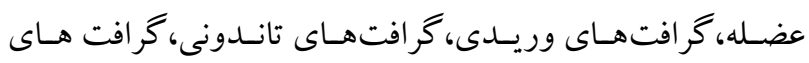

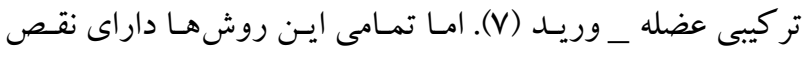
هستند.كانال هاى هدايت كننده عصب كه از مواد سـنتيكك سـاخته

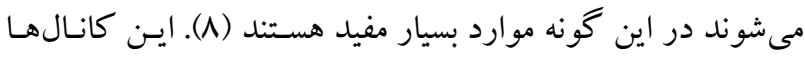
بدليل قطر بيشتر نسبت به عصب آسيب ديده اجازه رشـد مخروط آكسونى به طرف انتهاى عصب را فراهم مى كنتـد. عـلاوه بـر ايـن

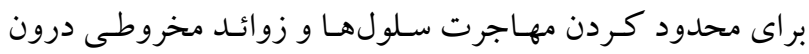
محدوده لوله، فضايى براى افزايش موضعى غلظت فـاكتورهـاى

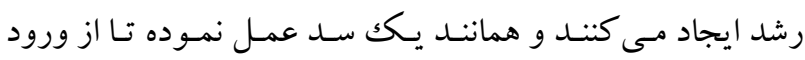

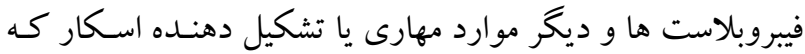

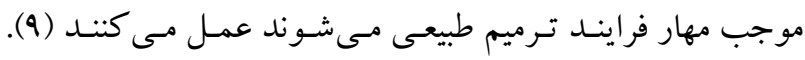

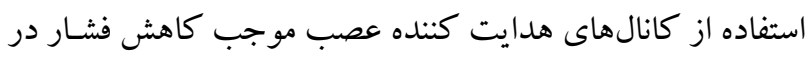

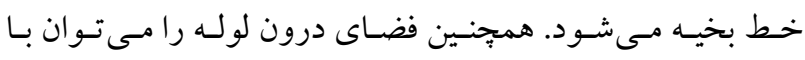

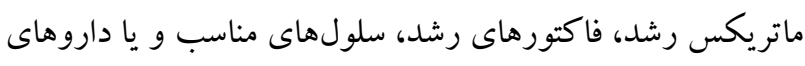

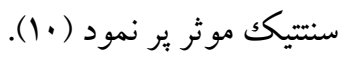

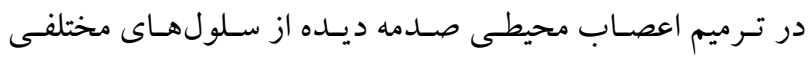
استفاده مى شود مثل سلولهاى مغز استخوان، فيبروبلاست، سلول -
مقدمه

در صدمات عصبى شديد مطالعات هدايت عصب و الكتروميو گرافى شاهدى بر تماميت عصبى هستند. همجنين در مورد زمان و مقدار بهبودى عصب اطلاعات قابل اعتمادى فراهم مى كنند. بهبودى آسيب عصب محيطى از طريق سه مكانيسم صورت مى گيرد: () ساخت مجدد ميلين(remyelination)

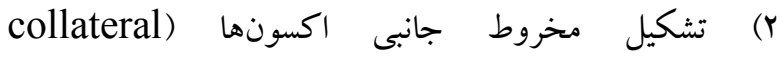
(sprouting و r r) ترميم از قسمت برو كسيمال محل ضايعه. ساخت مجدد ميلين سريعترين فرآيند جبرانى است و در عرض r Y-Y هفته صورت مى گيرد و بستخى به وسعت ضايعه دارد. در طى تخريب قسمتهاى ديستال اكسون ضايعه ديده، مخروط هاى جانبى كه در همسايكى اكسونهاى سالم قرار دارند، از اين اكسونها عصب دريافت كرده و به عضلات مربوط به آنها مى روند. اين فر آيند و-Y ماه طول مى كشد (1). در صدمات شديد اكسونى، جوانهاى جانبى براى فراهم نمودن عصب براى تمامى رشتهاى عضلانى كافى نيستند. در اين موارد، ترميم بيش از 11 ماه طول مى كشد. مطالعات هدايت عصب (NSC) و الكتروميو گرافى(EMG) در ارزيابى اختلالات عصبى لازم و ضرورى مىباشند (Y). اين مطالعات در متمركز نمودن محل ضايعه مفيد هستند. همجنين در تشخيص قطع هدايت عصبى(neurapraxia) در اكسونهاى تخريب شده مفيد

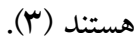
در طى اكسونوتمزيز و نوروتمزيز ارتباط يريكاريون و اكسون قطع مىشود و سطح كلسيم داخل اكسونى افزايش مىيابد، قطعات اكسونى جدا شده متورم مىشوند و يّاسخ دهى الكتريكى در طى rا-ها روز بعد از آسيب كاهش مىيابد (1). زمان مورد نياز براى بهبود آسيب عصبى به نوع صدمه و همجنين همكارى بين ساخت مجدد ميلين، تشكيل جوانه جانبى و ترميم اكسونى وابسته است. برگشت مجدد هدايت عصبى بعد از نور آيراكسيا وابسته به ساخت مجدد ميلين محل آسيب ديده است. زمان بهبود به فاصله ضايعه از عضلات بدون عصب شده وابسته است. سرعت ترميم ديستال Y-1 ميلى متر در روز مىباشد (F). بيش نياز ترميم عصبى، لولههاى تشكيل شده توسط سلولهاى شوان سالم است 
علوم يز شكى سـمنان در شـرايط نـور، آب و غـذاى مناسـب و در قفسهاى بِلاستيكى نغهدارى شدند.

\section{كروه بندى حيوانات}

حيوانات به هـ خروه تقسيم شدند كه عبارتند از:

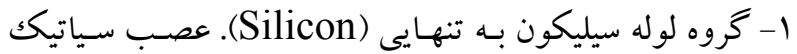

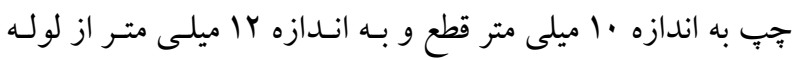

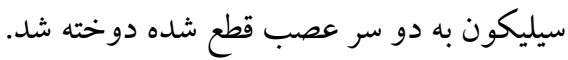

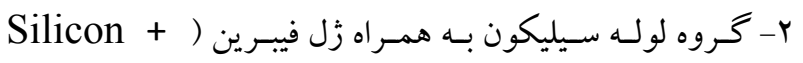
Fibrin

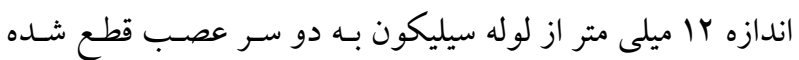
دوخته شد و ؟/ • ميلى ليتر از زل فيبرين درون لوله تزريق شد.

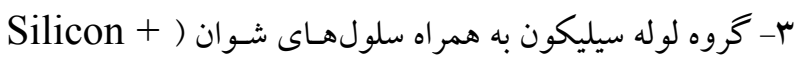
Fibrin + Schwann cells

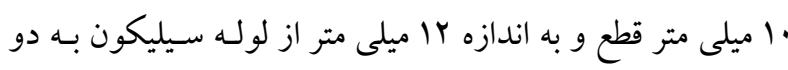

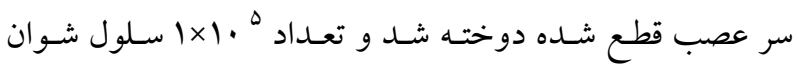
بدرون لوله سيليكون تزريق شد.

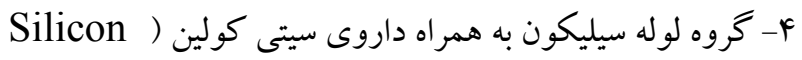
1. Fibrin + Citicoline

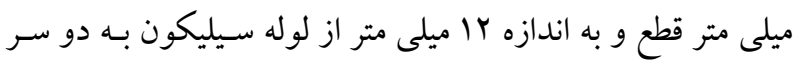

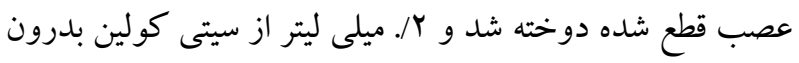

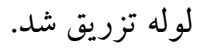

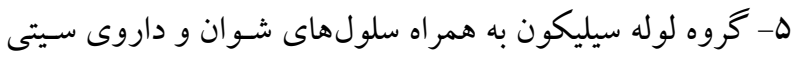
Silicon + Fibrin + Schwann cells+ ( كـولين

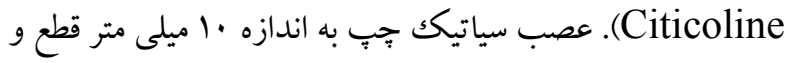
به اندازه r ا ميلى متر از لوله سيليكون به دو سر عصب قطع شـده

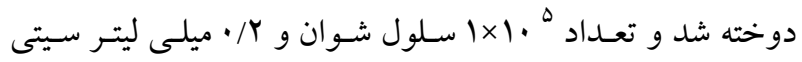
كولين بدرون لوله تزريق شد.
هاى بنيادى فوليكول مو و سلولهاى شوان (11). سلولهاى شـوان كه مسئول توليد غلاف ميلين اطراف اكسون ها هستند در صورت

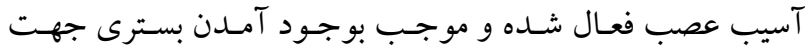

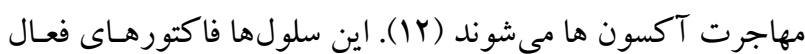
كننده اى رها مى كنند كه مهاجرت عصـب را افزايش مس دهند.

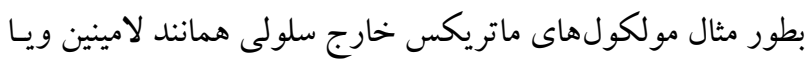
تعسدادى مولكول جسـبنده سـلول عصـبى (N-CAM) و كـلازن

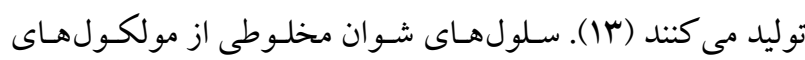

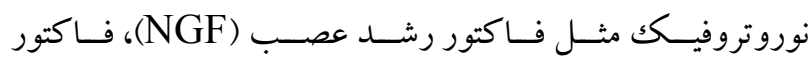

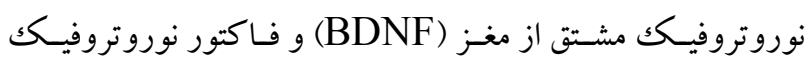

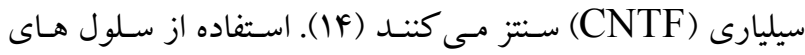
شوان در باى بسهاى (NGC) كه كانال فيبرينى توليـد مس كنــــ موجب تسريع در تشكيل طنابهاى بونگنر شده و يكك منبع مداوم

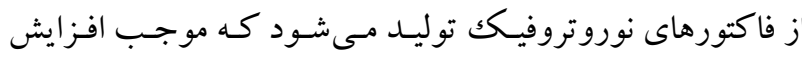
كيفيت ترميم عصب مىشود (1ه) سيتى كولين دارويى است كه در صـدمات نـورو دزنراتيـو سيستم عصبى مركزى موثر است. اين دارو موجب كاهش شكسته شـدن غشاى سلولى و توليد اسيدهاى جرب آزاد و توليدات سمى بافت صدمه ديده مى شود و همجنين سيتى كولين موجب ارتقا بقـاويـا

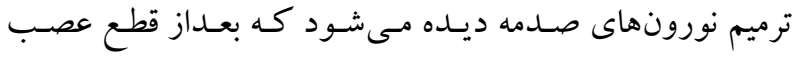

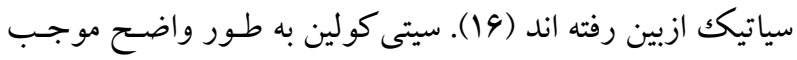

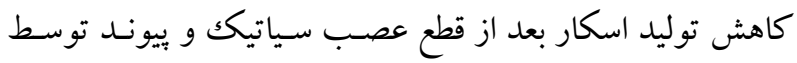
بخيه مىشود (IV). بنابراين در اين طرح براى اولين بار از تركيب

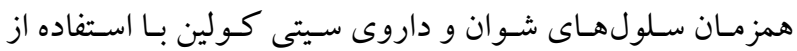
داربست لوله اى سيليكونى ير شده با فيبرين بـراى ترميم عصـب سياتيك در مدل قطع عصب استفاده شده است.

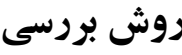
حيوانات

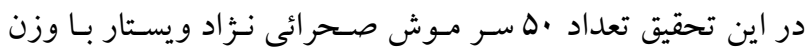

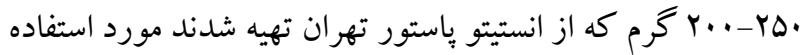
قرار گرفت. در مـدت تحقيق حيوانـات در حيوان خانه دانشـاه 
سلولها سه بار به مدت · ادقيقه درون PBS شستشو داده شـدند.

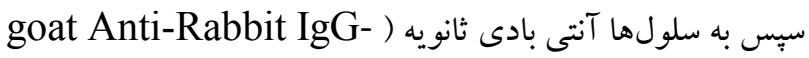

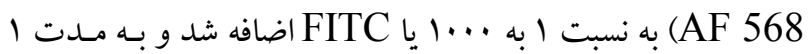
ساعت در دماى اتاق انكوبه شدند. در انتها سلولها مجددا سه بار و

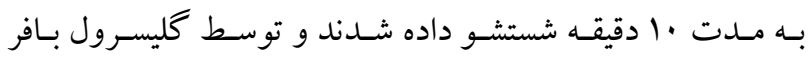

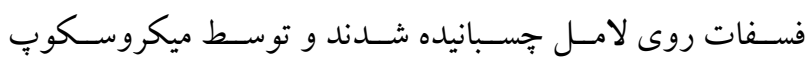
فلوئورسنت Olympus مشاهده شدند.

\section{روش ساخت داربست فيبرينى و جراحى در كروههاى} مورد مطالعه

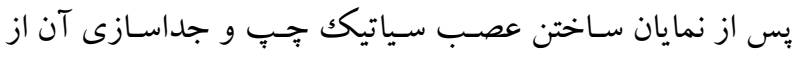

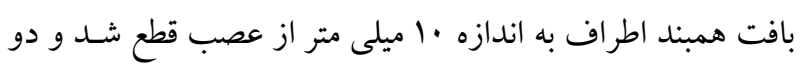

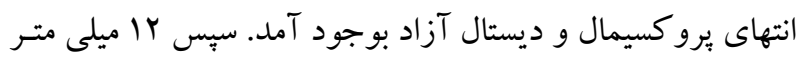

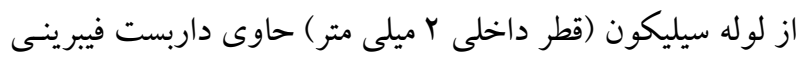

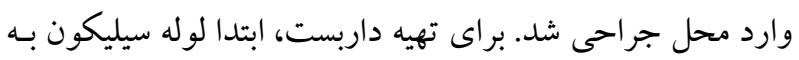

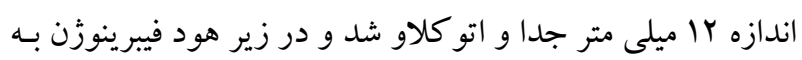
درون آن تزريق شد. با استفاده از سرنگك انسولينى ابتدا فيبرينوزن دئن

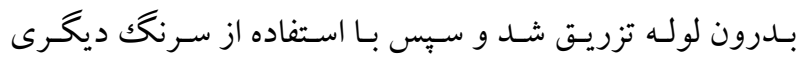

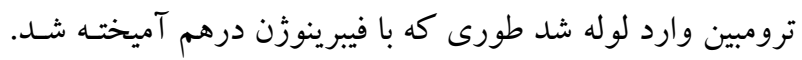

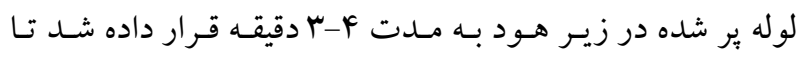

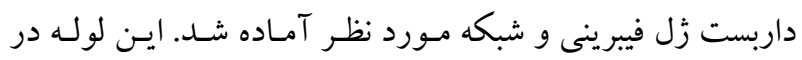

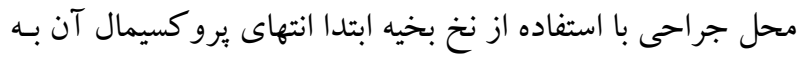

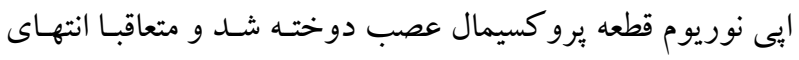
تحتانى آن به قطعه ديستال عصب دوخته شــــ جهـت اطمينـان از

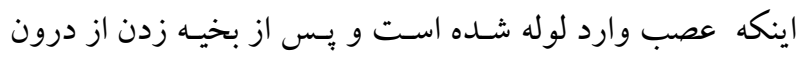

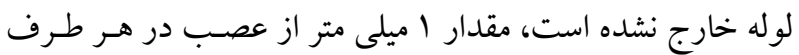

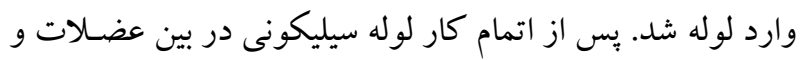

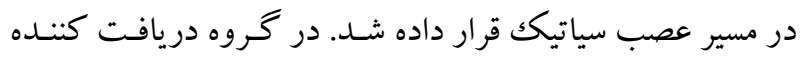

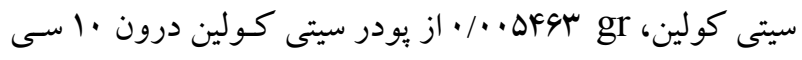
سى آب مقطر حل شد و محلول حاصـل در زيـر هـود فيلتـر شـد.

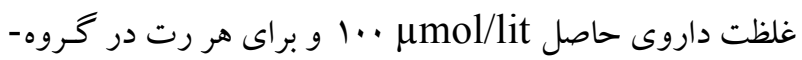
هاى مورد مطالعه Y/ • ميلى ليتر بدرون لوله سيليكون تزريق شـد.

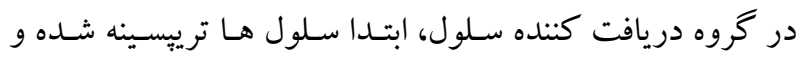

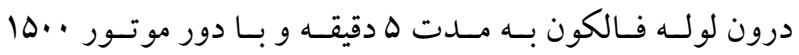

\section{روش كشت سلولهاى شوان}

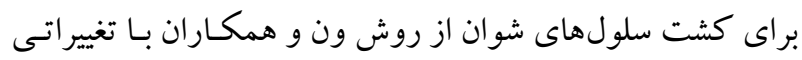

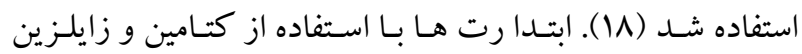
بيهوش شدند، يوست كنار زده شد و عصب سياتيك نمايان شـد.

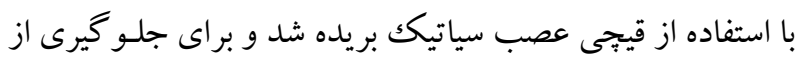

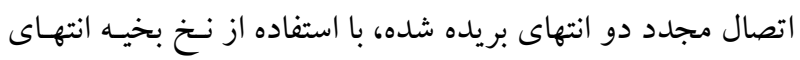

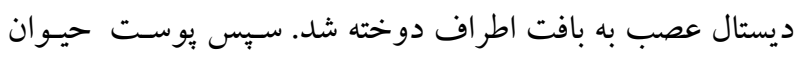

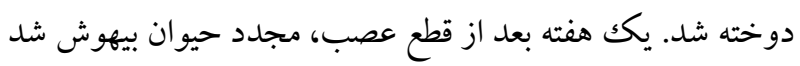

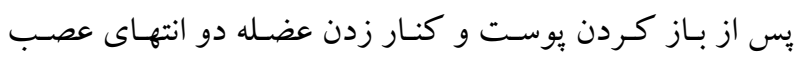

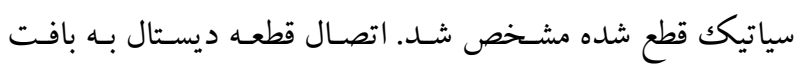

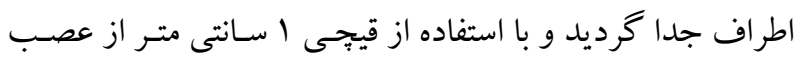

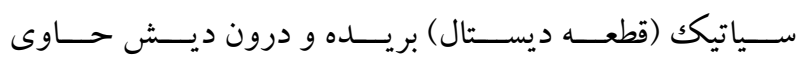

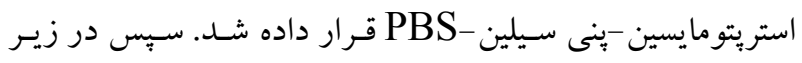
ميكروسكو پ إيى نوريوم عصب جدا و آماده هضم سـلولى شـد.

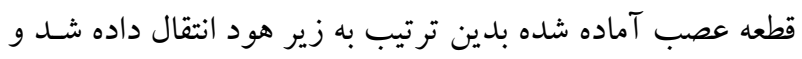
در ديشهاى حساوى آنتى بيوتيكك و PBS شستشـو داده شـد و

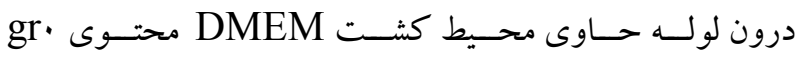

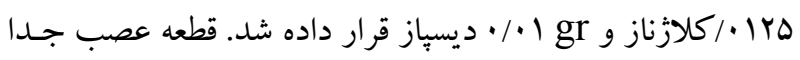

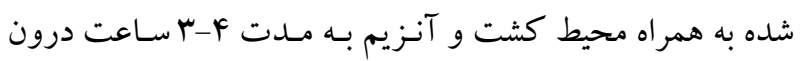

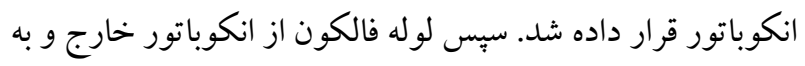

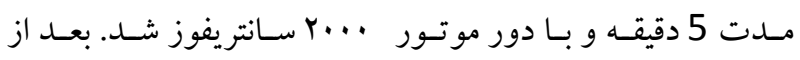
سانتريفوز مايع رويى خارج و بـه آن محيط كشـت بـدون آنزيم

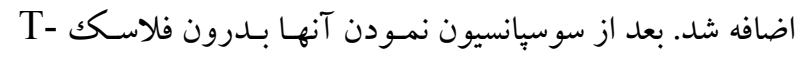

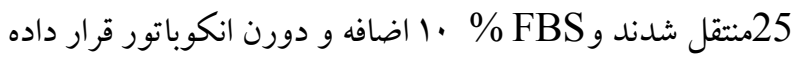
شد. محيط كشت سلول ها هر FN ساعت يكبار تعويض شد. روش ايمونوسيتوشيمى سلولهاى شوان

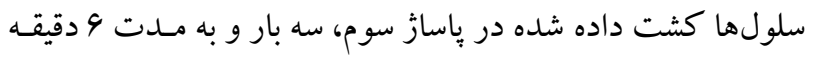

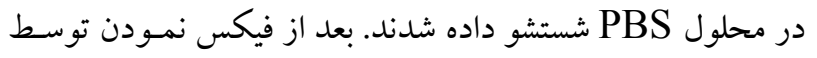

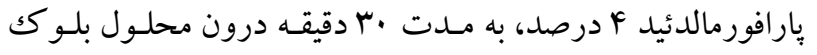

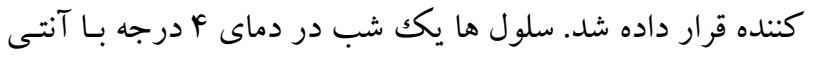

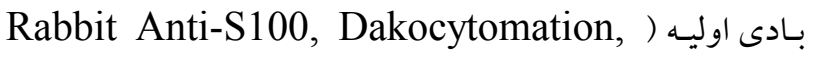
PBS $+0.3 \%$ Triton X + به نسبت ا بـه . له در (sigma 10\% Normal Goat Serum 
لوله سيليكونى حاوى عصب ترميم شده نمايان شد و يـس از جداسازى لوله از بافت اطراف، دو انتهاى عصب بريده شد و

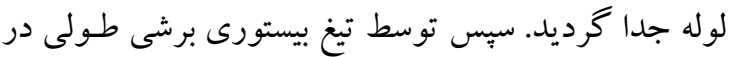

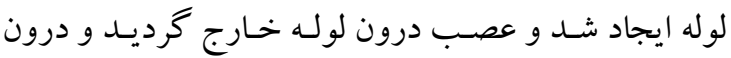

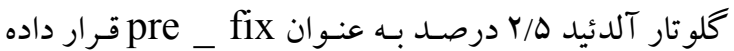

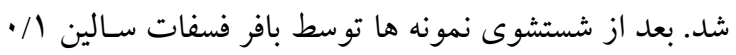
مولار به مدت ها دقيقه مراحل بافتى انجام گرفت. با استفاده

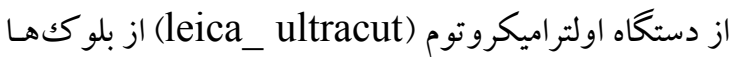

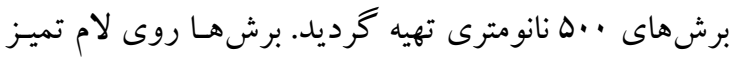

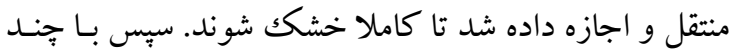
قطره محلول رنخك تولوئيدين بلو ا درصد رنخك شـدند. بعـد از شستشوى لام با آب مقطر و خشك شدن آن بر روى لام، با ميكروسكوبٍ نورى ( Olympus,PROVIS Ax 70,

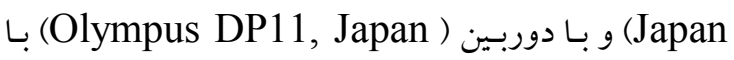
بزر كنمايى 400X تصاوير تهيه شد و سبس تصاوير با گريد

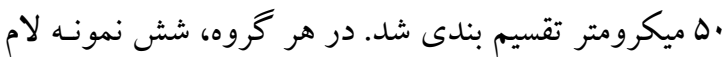

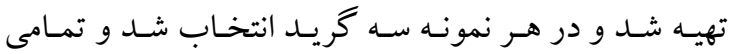
اكسونهـاى موجـود (داراى ميلين و فاقـد ميلين) شـمارش شدند و ميانگين اعداد بدست آمده به عنوان تعداد اكسون-

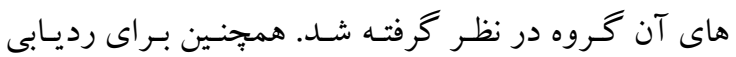

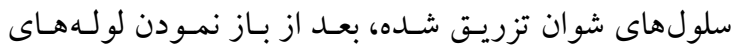
سيليكونى، بافت ترميم شده توسط OCT قالب گيرى شد و

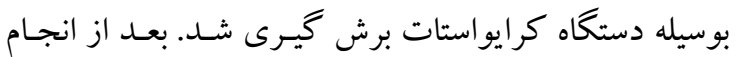

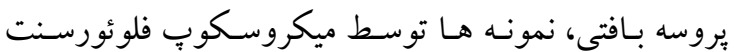
مورد مشاهده قرار خرفتند.

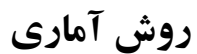

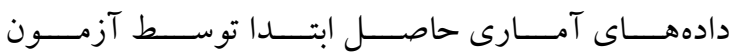

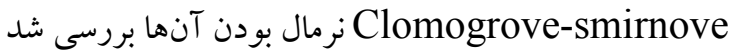
و با توجه به ه>•PC) بدست آمده، آزمون آمارى واريانس

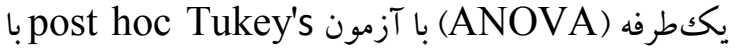

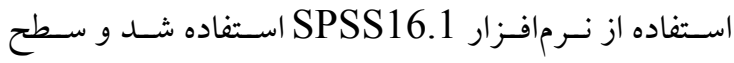

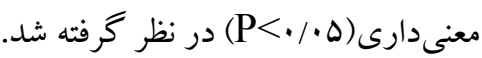

سانتر يفوز شــند. بعـد از سـانتريفوز، مـايع رويسى خـارج و يلـت سلولى با مار كر سيتويلاسمى و غشاى سـلولى DiI نشـاندار شـــ. بطور خلاصـه، سـلول هـا بـا •هT ميكروليتـر PBS شستشـو داده

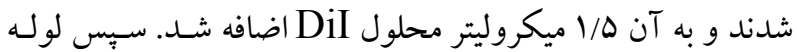
كه حاوى يلت سلولى و PBS و DiI بود بـه مـدت •r دوقيقهـ درون انكوباتور قرار داده شد. مجددا سلول هـا هـ دقيقهـ و بـا دور

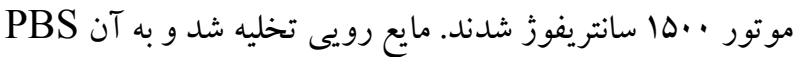

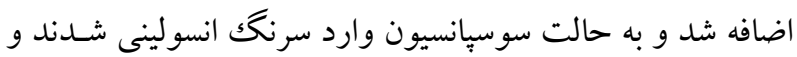
به درون لوله سيليكونى تزريق شـدند. بعـد از اتمـام كـار، يوست

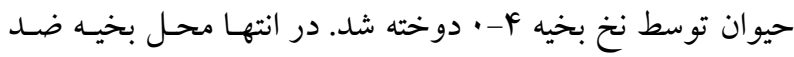

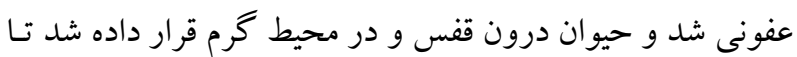

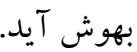

روش الكتروميو كر افى (EMG)

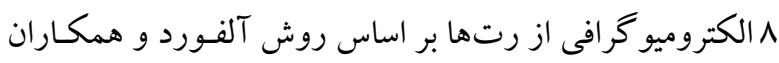

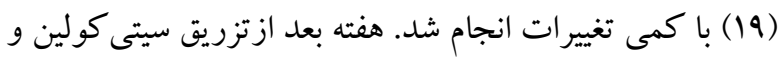

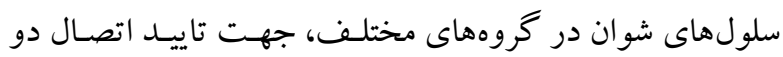
قطعه يرو كسيمال و ديسال عصب و كارايى عصب ترميم شـده،

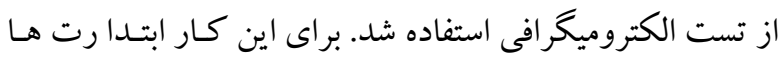
بيهوش و يوست محل جر احى باز شد. يوست تـا قسـمت يـايين

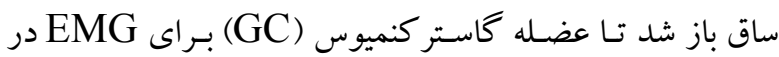

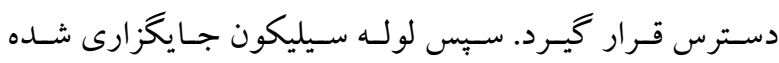
مشخص شد. در انتهاى يرو كسيمال لوله، دو الكترود تحريكك دهنـــ Stimulator Electrodes قـرار داده شــــ الكتـرود زمين Ground Electrodes نيز وارد قسمت شـكمى رت

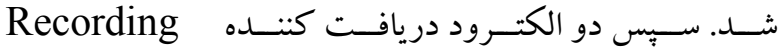
Electrodes بر روى عضله گاسترو كنميوس و زانوى رت قرار

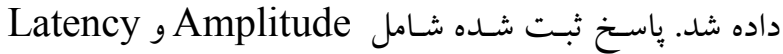
است. پِس از اتمام كار قسمت جراحى شـده را كـه شـامل لولهه سـيليون و عصـب درون آن مس باشـــ برداشـته و وارد محلـول فيكساتيو جهت بررسى بافتى شد. روش رنك آميزى بافتى

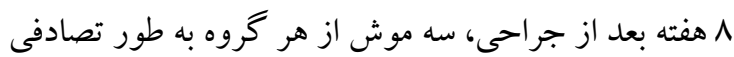

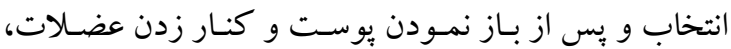


طور اختصاصى در اين سلول ها ترشح مىشود را بيـان مى - كئ

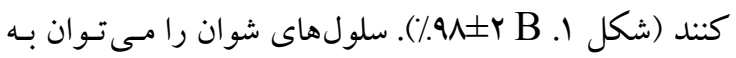

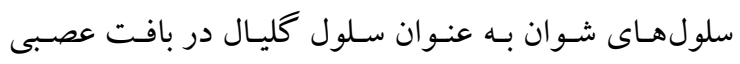

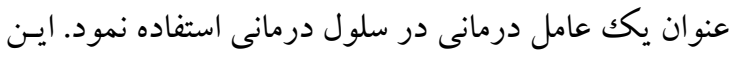
محيطى هستند و توانايى تقسيم بالايى دارند. اين سلولها در

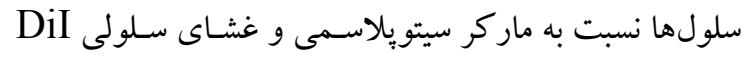
محيط كشت قابليت جداسازى و تكثير و تمـايز دارنـد. ايـن

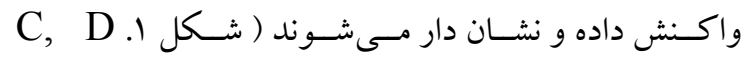
سلول ها در ياسخ به آسيب وارد شده شروع به تقسيم نموده .$(\% 9 \nabla \pm r$

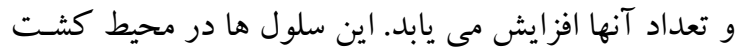
به صورت فيبروبلاسيت و دوكى شكل ديده مى شوند (شكل

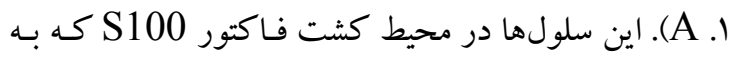
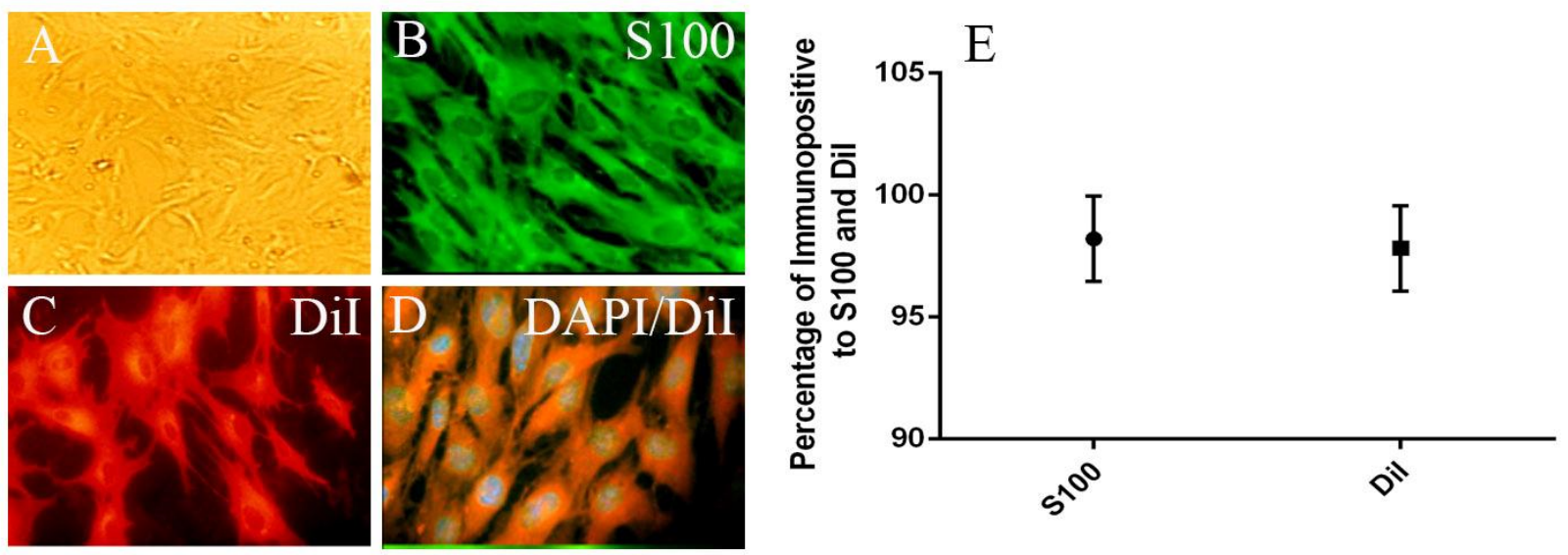

شكل ا: سلولهاى شوان كشت داده شده و بيان مار كر اختصاصى آن. سلولهاى شوان در هاساز سوم (A) به صورت سلولهاى دوكى شكل ديـده مسىشوند.

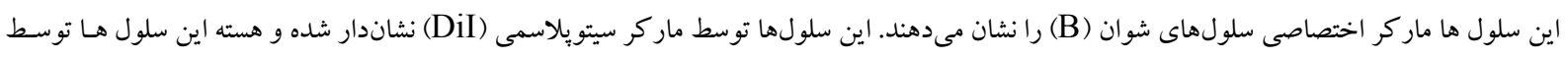

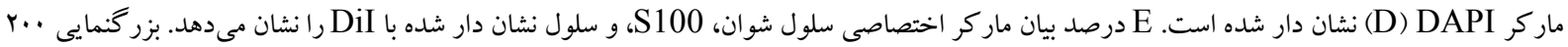
A-D ميكرومتر براى 
دهد كه سلولها شوان بيوند شده توانايى بقا و مهاجرت در محيط آسيب ديده عصبى را دارند. تجمع سلولهـاى بيونــ شده بيشتر در محيط لوله ديده مىشود و كمتر در مركز قرار

دارند.

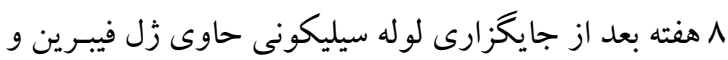
سلولهاى شوان (شـكل r. Y-D)، نمونـه عصسب سـياتيك ترميم شده خارج شـــ و سـلولهـاى نشـان دار شـده توسط ماركر DiI بيوند شـده رديـابى شـدند. تصـاوير نمونـهــاى ايمونو هيستوشـيمى (شـكل r. B-D) نشـان مـى دهنــد كـه سلولها شوان نشـان دار شـده بعـد از ييونــد توانسـته انـلد در محيط يبيوند شده زنده مانده و شروع به مهاجرت نمايند. اين سلول ها تقريبا در تمامى قسمت ها لوله از جمله در مركز و در محيط لوله سيليكونى ديده مى شوند. اين يافته نشان مسى -
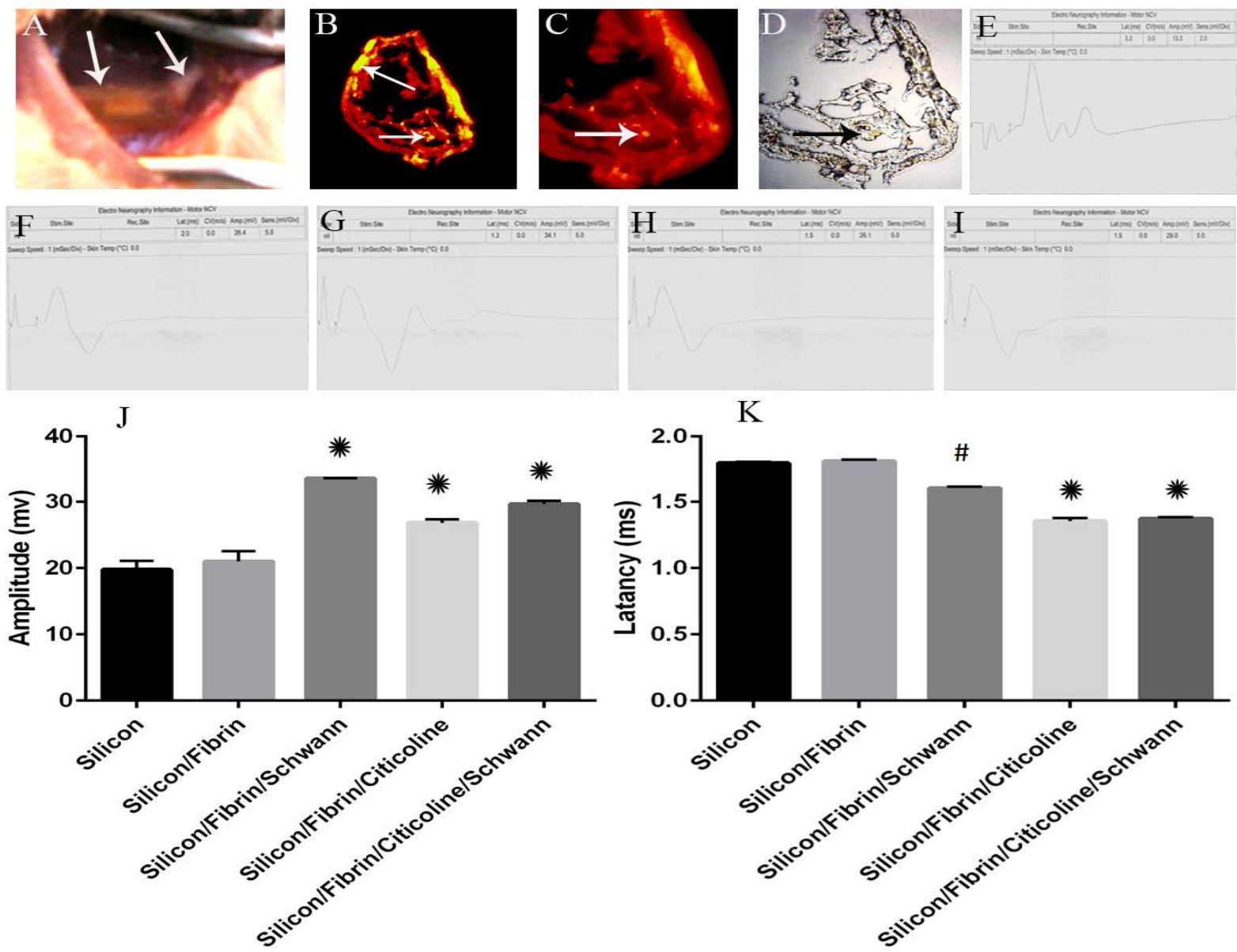

شكل r: قرارگيرى سلولهاى شوان تزريق شده در لوله سيليكونى در گروههاى مختلف و تاثير بر ميزان دامنه موج و تاخير در هدايت عصبى. A-D سلولهاى شوان نشان دار شده با مار كر DiI در محل ترميم يس از م هفته با ضخامت Vميكرون را نشان مىدهد. با اين روش حضور سلولهاى شوان در محل

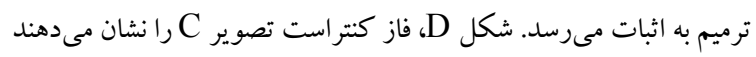


نشان دهنده كارايى بهتـر سـينايس ايجـاد شـده و در نهايــت عصب ترميم شده مىباشـد. Amplitude (شـكل r. J) در نمودار نشان دهنده دامنسه مـوج الكتريكى اسـت و نماينـده تعداد واحدهـاى حركتى در عضـله مسىباشـــ و هـر جِقدر بيشتر باشد نشان دهنده وجـود واحـدهـاى حركتى بيشـتر و كارايى بيشتر عصب تـرميم شـده مسىباشـد. در مقايسـه بـين ميانخين دامنه موج الكتريكى در گروههاى مورد مطالعه در

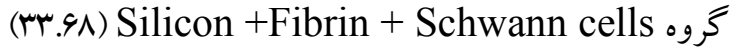
) Silicon + Fibrin + Citicoline بـا گرووهـاى Silicon + Fibrin + Schwann + , (r\&.90 Citicoline ( $(P<0 / 05)$ دامنه موج الكتريكى در گروههـاى مـورد مطالعسه در گـروه و(Yฯ.90) Silicon + Fibrin + Citicoline ) Silicon + Fibrin + Schwann + Citicoline • . دار اسـت. در مقايسـه بـين ميـانخين اى تـاخير در هـدايت Silicon الكتريكى در گروه هاى مورد مطالعه در گحروه Silicon با گروه Silicon + , (1.r4) + Fibrin + Citicoline (I.rv) Fibrin + Schwann + Citicoline اختلاف آمارى كمتر از ه•/ (ه • (P<) معنى دار اسـت. همجنين در مقايسه بين ميانگين تاخير در هدايت الكتريكى احتى Sر كروههاى مورد مطالعه در گرووه Silicon + Fibrin Silicon + Fibrin + (1.rq) + Citicoline

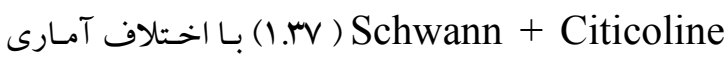
كمتر از ه • • (ه • • ( $)$ • معنى دار نيست. نتايج بروسى بافتى به روش تولوئيدين بلو
فلش ها در B, سلولهاى شوان نشان دار توسط DiI را نشان مىدهند. سلول ها بيشتر در حاشيه مقطع ديده مىشوند كه بدليل جسبيدن سلول هاى شوان به ديواره لوله سيليكون

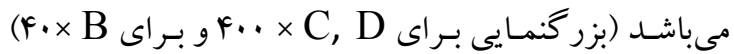

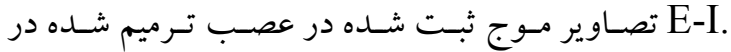
كروههاى مختلف بعد از 1 هفته را نشان مىدهد و اختلاف

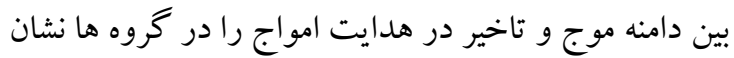

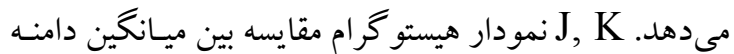
موج الكتريكى و تاخير در هدايت موج الكتريكى ثبت شده

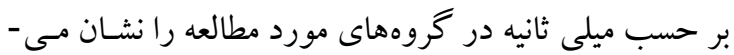

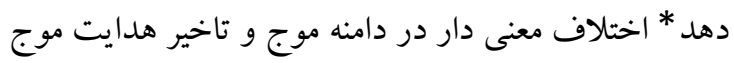

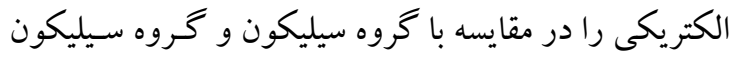

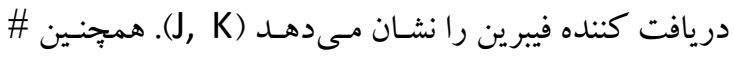

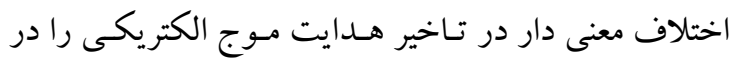

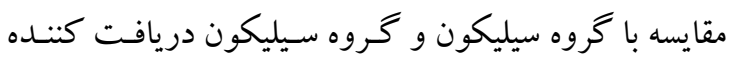

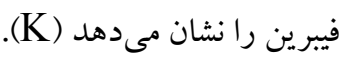
نتايج الكتروميوكر افى مغئ

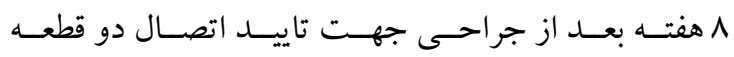
يرو كسيمال و ديسال عصب و كارايى عصب ترميم شـده، از

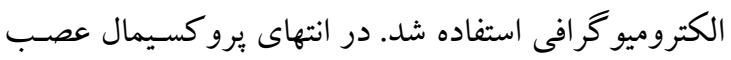

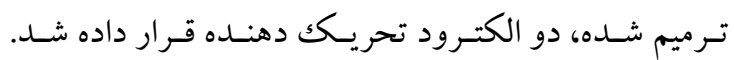

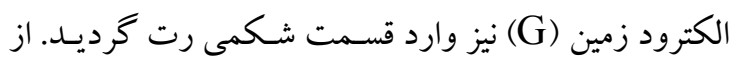

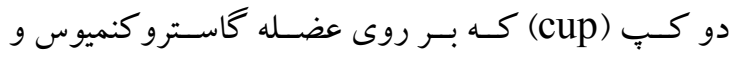
ديخرى بر روى زانوى رت گذذاشـته مسى شـود، استفاده و و

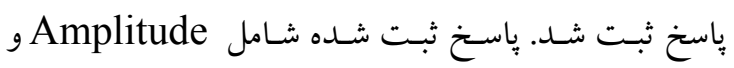

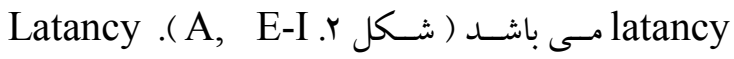

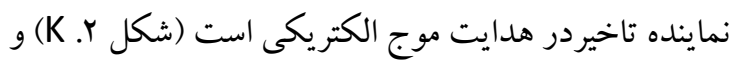

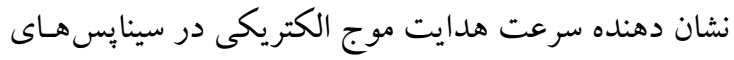
عصبى - عضلانى است و هـر جقـــر مقـدار آن كمتر باشـــ

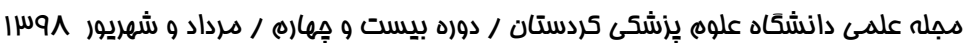


لبوبود سافتار و عملكرد... V4

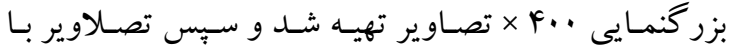
كريد ·له ميكرومترى تقسـيم بنـدى شـدند. در هـر گـروهاز شش نمونه، لام تهيه شد و در هر نمونه سه گريد انتخاب شد و تمامى اكسـونهـاى مو جـود (داراى ميلـين و فاقـد ميلـين) شمارش شدند و ميانخين اعداد بدست آمده به عنوان تعـداد اكسونهاى آن گروه در نظر گرفته شد.
^ هفته بعد از جراحى، عصسب تـرميم شـده را از درون لولـه سيليكون خارج كرده و برشهاى كرونال بـا ضـخامت . .0ه نانومترى از قسمت ميـانى عصسب تهيـه و بـر روى لام جمـع آورى و بارنكَ تولوئيدين بلو رنگك آميزى كرديـد ( شـكل شماره س). يس از قالب گيرى عصب ترميم شده و تهيه لام-

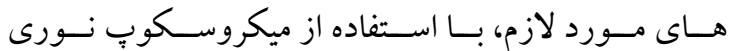
(Olympus,PROVIS Ax 70, Japan)
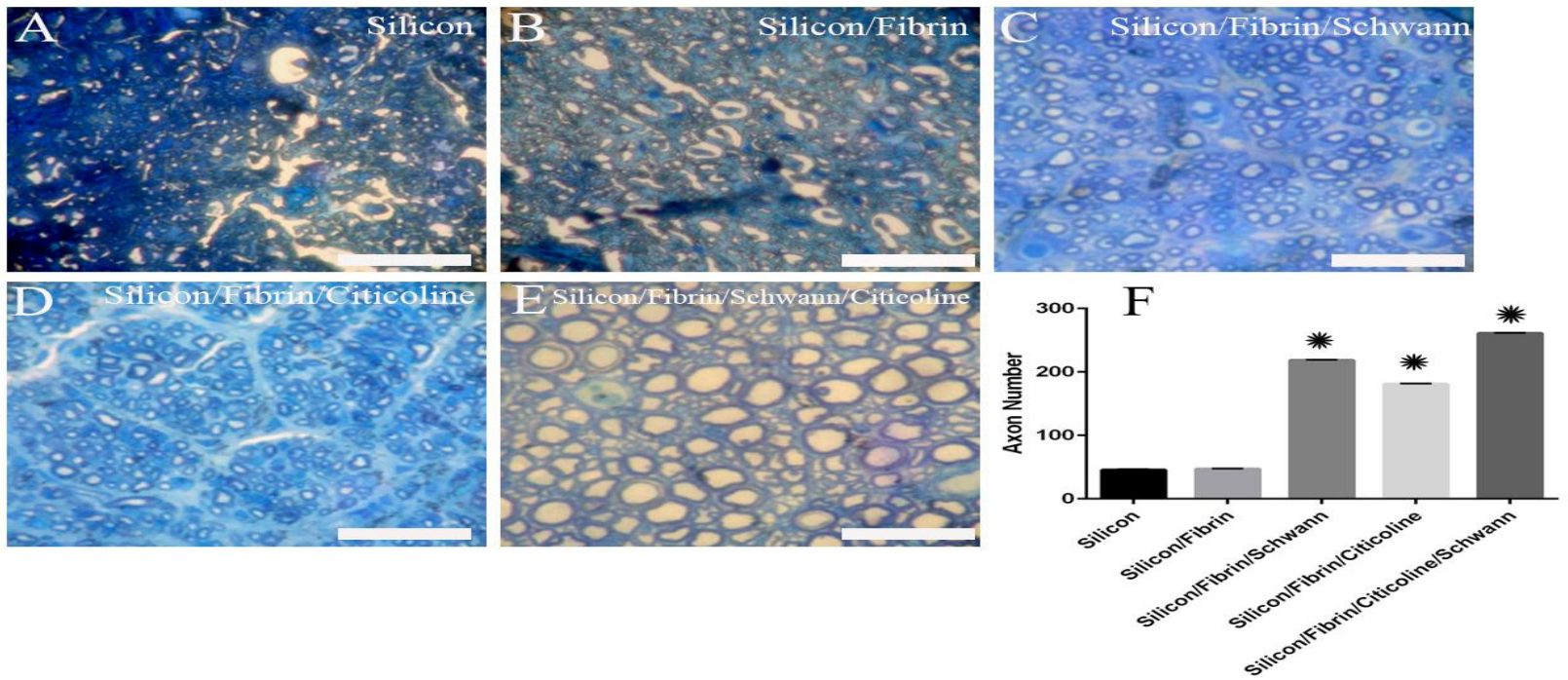

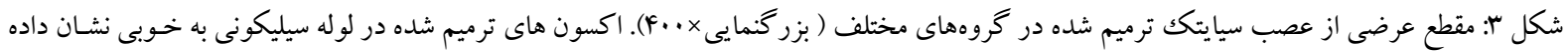

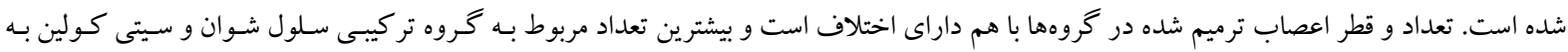

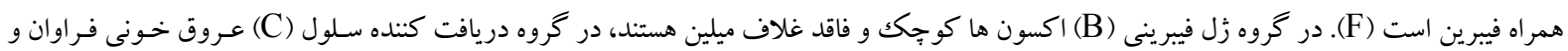

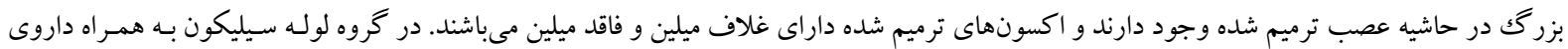

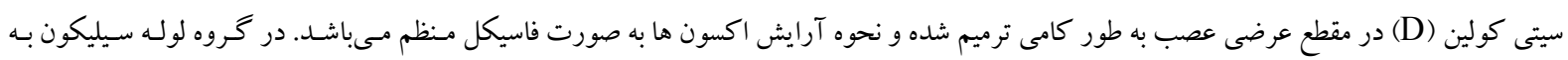

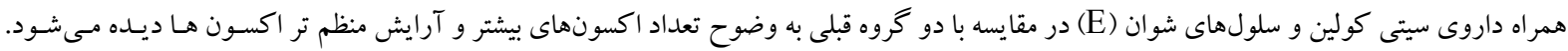

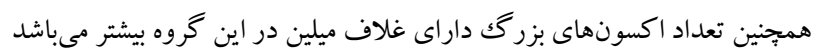


در مقايسه با ترميم اتو گرافت از جمله روش هايى است كـه

در ترميم عصب مورد توجه محققين قرار گرفته است (Y) (Y).

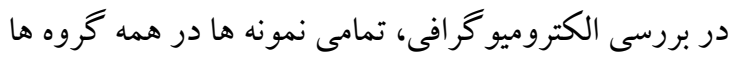

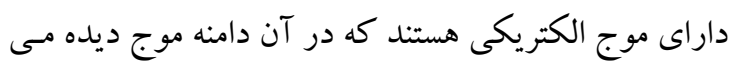

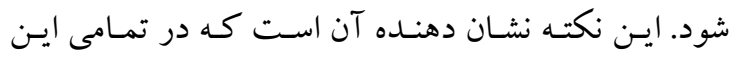
كروهها ترميم عصب و رشد اكسونى صورت كرفته است و و

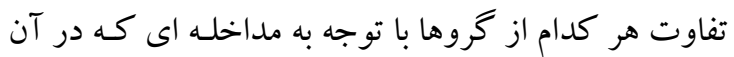

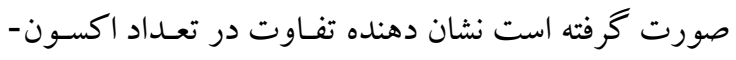
هاى ترميم شده مسى باشـد. از آنجـا كـه سـلولهــاى شـوان، محيط عصبى خارج سلولى را توسط سلولهاى بافر كننده و برداشت نوروتر انسميتر ها تنظيم مى كنند مى تو انند در انتقال عصبى (neurotransmission) دخالت كنتــ همجنسين سلولهاى شوان يـرى سينايتيك (PSCs) صففحه محر كه. انتهايى (motor end plate) را الحاطه مى كنتـد ـ بنـابراين

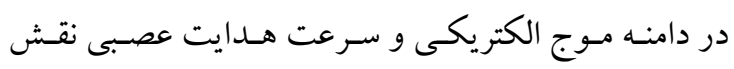

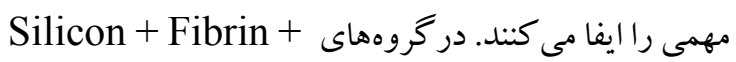
Silicon + Fibrin + Schwann + , Schwann دامنه موج بيشتر از ديخر گروهها اسـت (ه) Citicoline

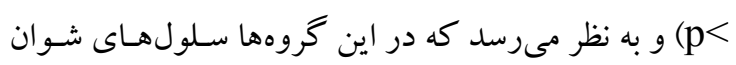

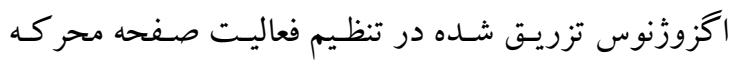

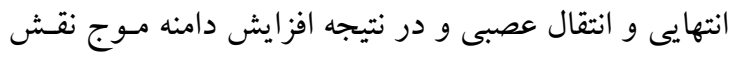
موثرى داشـته انـــ. استـفاده از داروى سـيتى كـولين كـه در كاهش اسكار شركت مى كنـد (rr, 19) نيز موجـب ايجـاد دامنه موج بيشتر نسبت به Silicon + Fibrin شده است فئ. در هـر دو گروه Silicon + Fibrin + Citicoline و و Silicon + Fibrin وجود دارد كه اين سلول ها نيز در تشكيل طنابهاى بونكنر

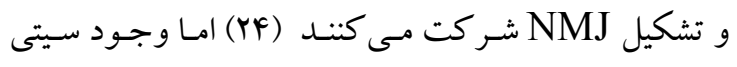
كولين به عنوان عامل مداخله اي نشان مىدهد كه ايـن دارو توانسته است در ايجاد موج الكتريكى بلندتر دخالـت داشـته باشد. در حقيقت سيتى كولين از طريق ارتقـا بقـا ويـا ترميم

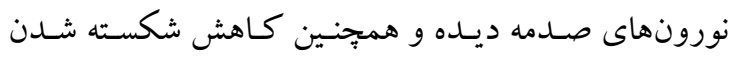

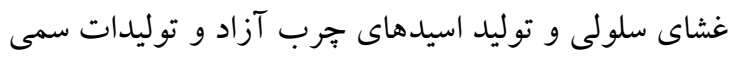

در تحقيق حاضر اثر داروى سيتى كولين و سلولهاى شـوان در ترميم عصب سياتيكك قطع شده بـا استفاده از يافتـهــاى

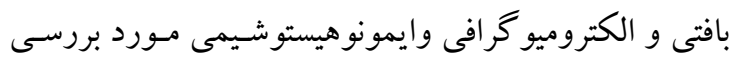

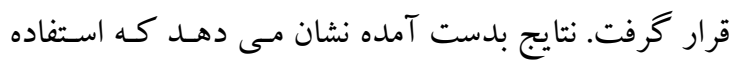

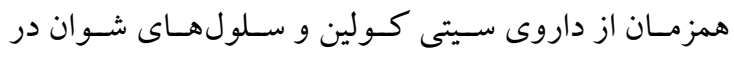
افزايش تعداد اكسونهـاى ترميم شـده و همجنـين افزايش كارايى عصب ترميم شده نقش موثرى دارد. تنه عصب سياتيك در موش صحرايى تقريبا ه/1 سانتى متر طول دارد و تحقيق با قطع بـيش از يـك سـانتى متـر، بــليل

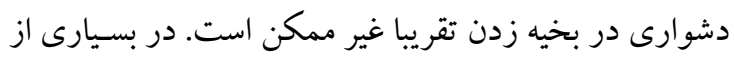

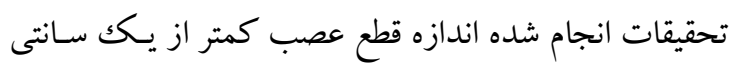

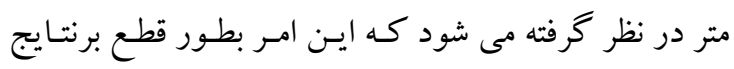

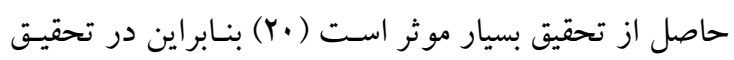

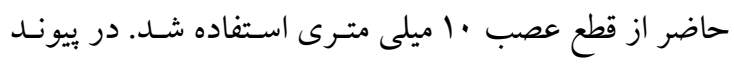

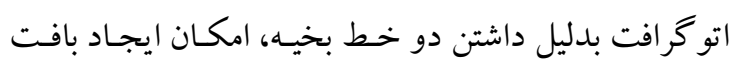

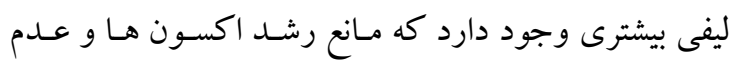
هدايت آنها در مسير صحيح مى شود. از آنجا كه در ترميم با NGCs، هر دو انتهاى عصب درون مجرا قرار مى گيرند،

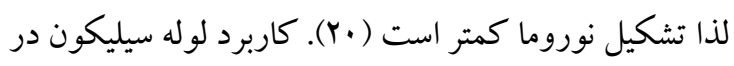

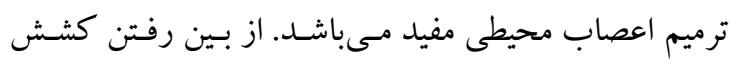

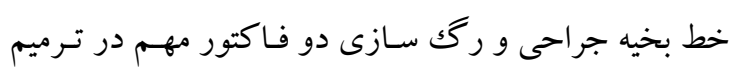

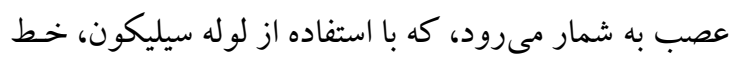

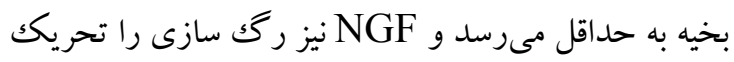

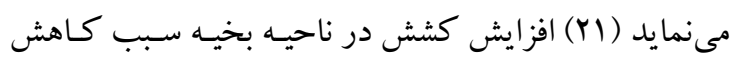
قطر عروق خونى تغذيـه كنتــه عصـب مسى شـود، در نتيجـه

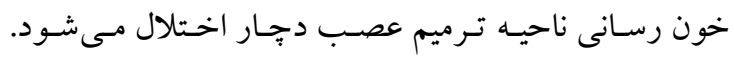
تشكيل عروق خونى نيز عامل مهمى در ترميم بافت به شمار

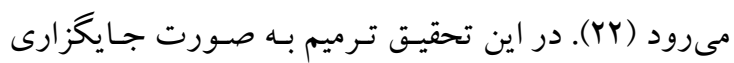
لوله سيليكون حاوى زل فيبرين به همر اه سـلولهـاى شـوان، داروى سيتى كولين و تر كيب هردو انجام كرفـت. برداشـت فئس

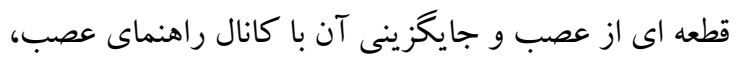
به دليل داشتن مزيتهايى از قبيل در دسترس بودن، تنوع آن 
با بررسى نمودار و تصاوير گروههاى مورد مطالعه ديده مى-

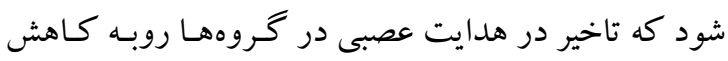
مىباشد. هر جقدر تاخير هدايت حر كتى كمتر باشـد مـدت

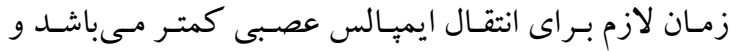
بنابر اين امواج عصبى با سرعت بيشترى منتقل مسىشوند كـه در عملكرد عصب ترميم شده تاثير مثبت دارد (Y) Silicon + كمترين ميزان تاخير هدايت حركتى در كروه Silicon + Fibrin + , Fibrin + Citicoline Schwann + Citicoline ايجاد شده بعد از آسيب عصبى در هدايت حر كتى اختلال ايجاد مى كند و از آنجا كـه سيتى كولين موجب كـاهش اسكار مسىشود (YY, 19) بنـابر اين همانطور كـه در فرضيه

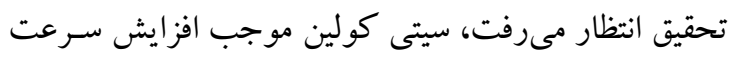

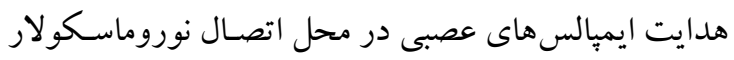

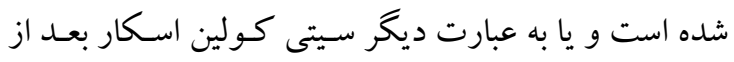

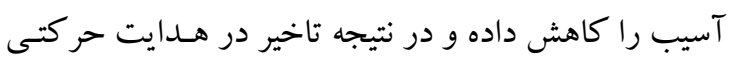

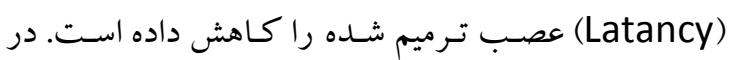
كروه Silicon + Fibrin + Schwann تـاخير هـدايت كر كتى نسبت بـ گرووههـاى Silicon + Fibrin + Schwann + , Citicoline Citicoline كروه Silicon + Fibrin كـاهش نشان مس دهــد، در حقيقت سلولهاى شوان اخزوزنوس تزريق شده توانسته انــ

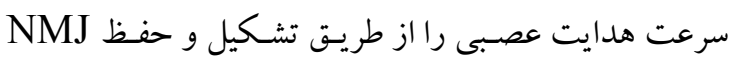

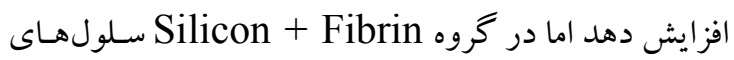
شوان اندوزنوس نتوانسته اند به اندازه سلولهاى اخزُرونوس در تشـكيل NMJ و افززايش هــايت عصبى نقـش داشـته

در بررسى ترميم اعصاب محيطى، تعداد اكسونهـاى ترميم شده از لحاظ تعداد و همجنين ميلين دار شـدن آنها و نيز بررسى كيفيت غلاف ميلين ترميم شـده، اطلاعـات مفيـىى جهت بى بـردن بـه مـوثر بـودن روش جراحى و تـداخلات درمانى فراهم مى كند (Y9). در بررسى بـافتى عصـب ترميم شده مى توان عروق ايجاد شده درون عصب در حسال ترميم
بافت صدمه ديده موجب افزايش دامنه موج الكتريكى مسى

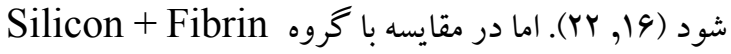
Schwann + دامنه موج كو تاهتر ديـده مسىشود. بـه نظر مىرسد كه در اين گروه كه فقـط داراى سـلولهـاى شـوان اندوزنوس فعال شده اند، اين سلول ها نتو انستهانـــ بـه طور كامل در انتقال عصبى دخالت داشته باشند. اين امـر رامى ســ

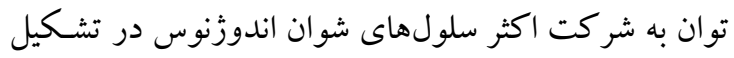

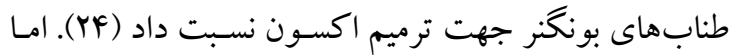

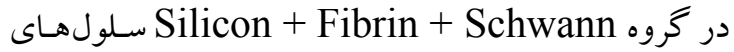
شوان اگزوزنوس در ايجاد و عملكرد NMJ دخالت داشتهن و در نتيجه موج الكتريكى بلند تر ديده مى شود. به طور قطع

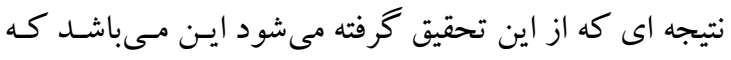

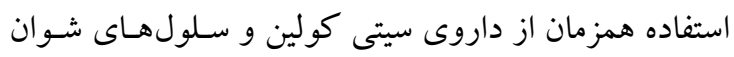
نقش بسيار خوبى در ترميم عصب و كـارايى عصدب ترميم

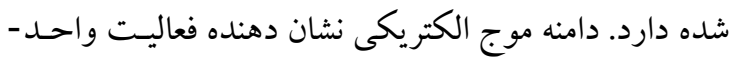

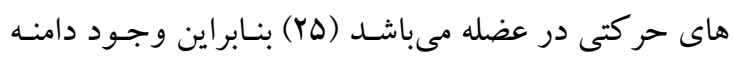

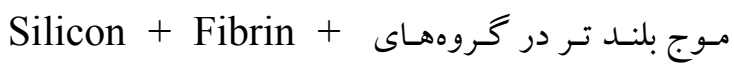
Silicon + Fibrin + Schwann + , Schwann نشان دهنده اين مطلب مىباشد كه واحدهـاى Citicoline

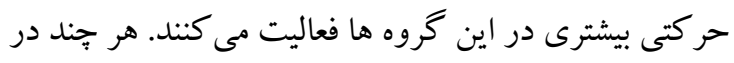
كروهى كه سيتى كولين به تنهايى استفاده شده است بـدئليل دامنه موج كو تاهتر احتمالا واحدهاى حركتى كمترى دراين

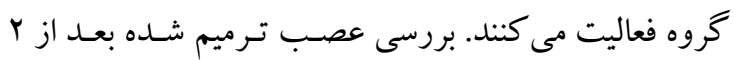

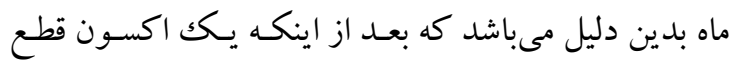
مىشود، فر آيند تخريب والرين در قطعه ديستال عصب براى

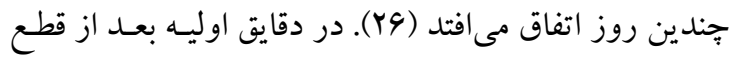
عصـب در طـى جنـــين روز اول، قطعه ديستال عصـب از لحاظ الكتريكى تحريكك يـــير اسـت. در طـى ايـن دوره،

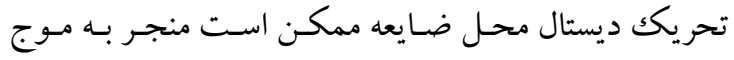
طبيعى و يا نزديكك به موج طبيعى شود. اكسونهاى حر كتى

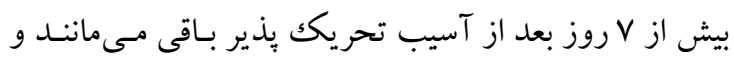

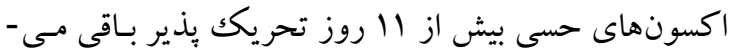

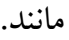




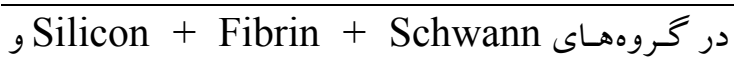
Silicon + , Silicon + Fibrin + Citicoline Fibrin + Schwann + Citicoline شده داراى نظم بيشتر و بهترى مىباشند. فاسيكل هـا در هـر

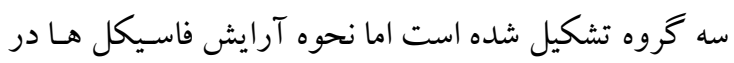
Sروه Silicon +Fibrin + Schwann + Citicoline Silicon + Fibrin + Schwann Silicon + Fibrin + اكسونهاى ترميم شـده در خروه Silicon بيشتر از گروههاى Schwann + Citicoline Silicon + Fibrin + , Fibrin + Schwann مىباشد همجنين قطر اكسونها نيز در گروه + Citicoline Silicon + Fibrin + Schwann + Citicoline بيشتر مسىباشـد. تعـداد اكسونهـاى ترميم شـده در گروه Silicon + Fibrin + Schwann + Citicoline داراى تفاوت معنى دارى با دو گروه ديخر مىباشد همجنين كروه Silicon + Fibrin + Schwann بـ خروه Silicon + Fibrin + Citicoline

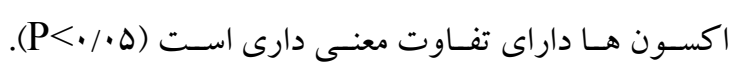

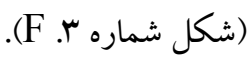
در بررسى ايمونو هيستو شيمى عصب ترميم شـده درون لوله سيليكون (شكل شماره r. . B-D) ديده مى شود كه سـلول-

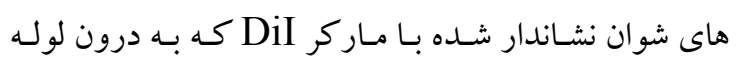

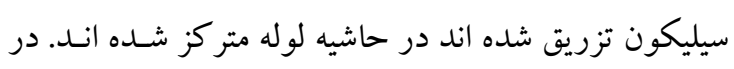

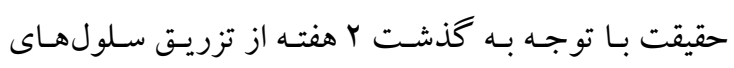

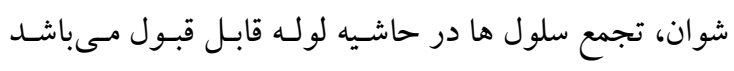

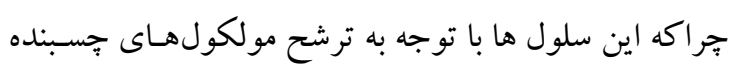

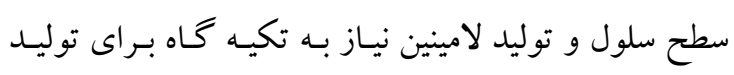

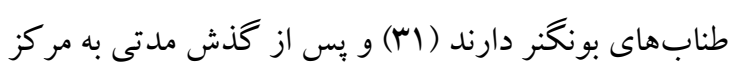

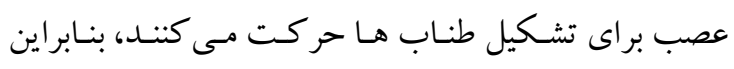

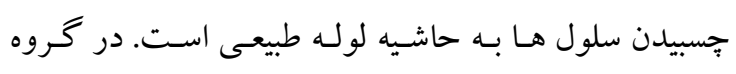
Silicon + , Silicon + Fibrin + Schwann Fibrin + Schwann + Citicoline بيشتر از گرووهSilicon + Fibrin + Citicoline مسى
را نيز مورد توجه قرار داد. يكى از مواردى كه در استفاده از

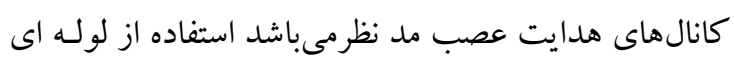

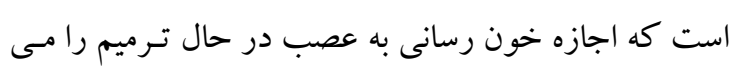

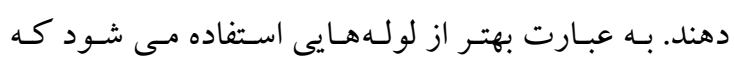

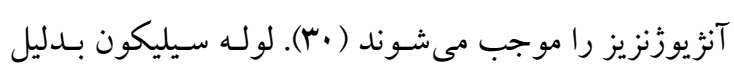

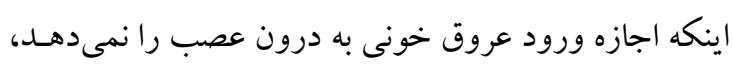

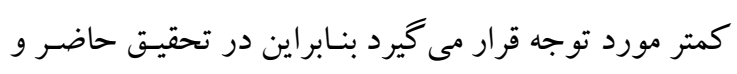
در بررسى بافت عصب ترميم شده، توجه به وجـود و تعـداد

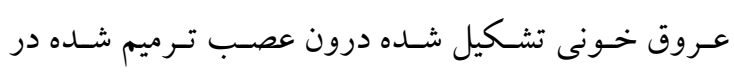

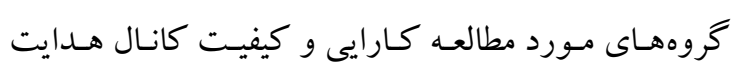

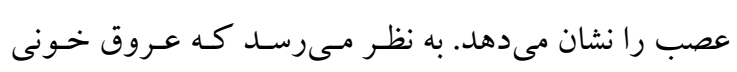
تشكيل شده در خروههـاى مـورد مطالعهـ بـه دليـل حضور

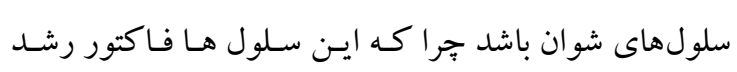

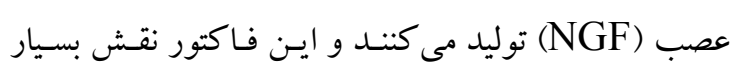

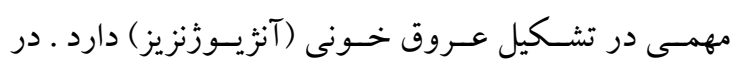

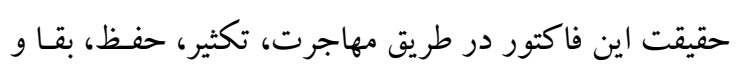

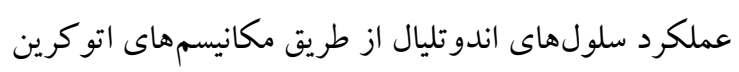

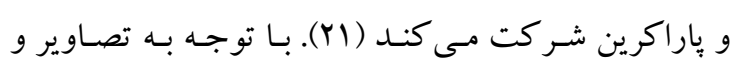

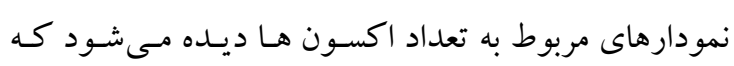

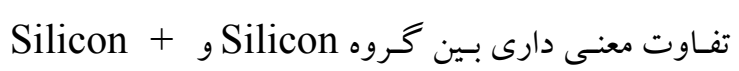
Silicon + Fibrin + Schwann و كروهواى Fibrin Silicon + Silicon + Fibrin + Citicoline Fibrin + Schwann + Citicoline

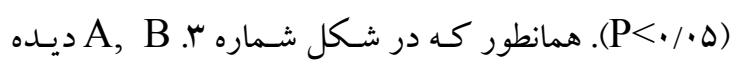

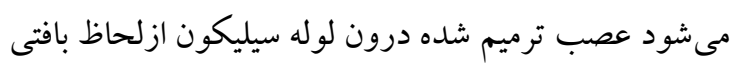
با عصب سياتيك طبيعى تفاوت دارند. درون عصسب ترميم

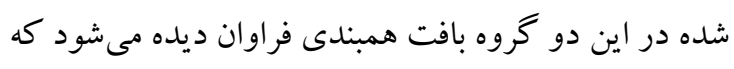

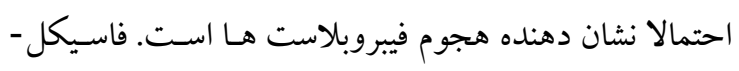

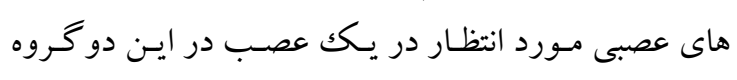
ديده نمى شود و در ضمن اكسونهاى ترميم شــده نيـز اكثـرا

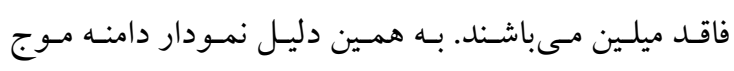

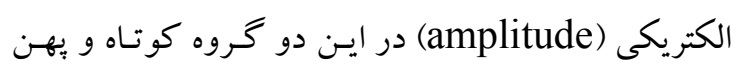
ديده مى شود كه با نتايج بافتى آن مطابقت دارد. 


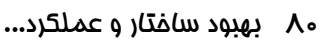

از كانال سيليكونى براى ير نمودن ايـن فاصـله استفاده شـــ. بخيه زدن دو انتهايى عصب به دو سر لوله كشش و فشـار را از روى عصب بر مىدارد اما اسكارى كه در محل بخيه بـهـ وجود مى آيد مى تواند در ترميم بافت اختلال ايجـاد نمايـــ.

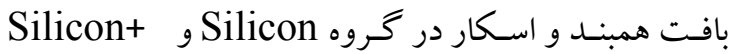

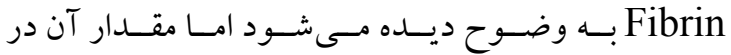
كروه Silicon + Fibrin + Schwann كاهش يافته است. در گروهـSilicon + Fibrin + Citicoline كـ از داروى سيتى كولين بطور منفرد استفاده شده است اسكار در مقايسه با خروههاى ديخر كاهش داشته اسـت بـه طورى كه در اطر اف عصـب ترميم شـده بافت غيـر عصبى ديـده نمى شود به عبـارت ديخـر در حاشـيه عصـب همانتـد مر كز

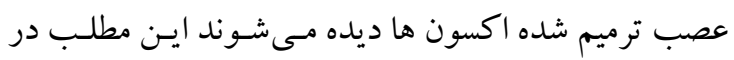

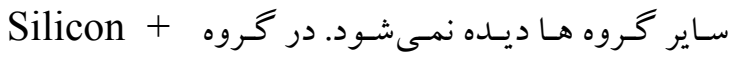
Fibrin + Schwann + Citicoline از سيتى كـولين حاشـيه عصـب و در نتيجـه اسكار كمتـر از كروه Silicon + Fibrin + Schwann مسى باشــ كـه

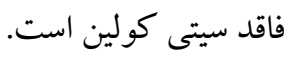

\section{نتيجه كيرى}

بر خلاف سيستم عصبى مر كزى، سيستم عصبى محيطى

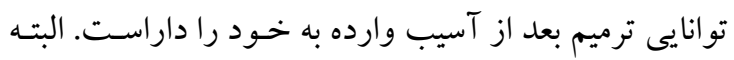

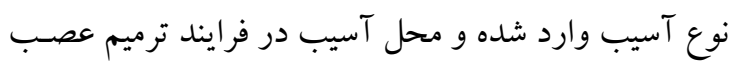
بسيار مهم مىباشند. امروزه از مواد بسيار متنوعى در ترميم اعصاب محيطى استفاده مى شود. اما عامل اصلى ترميم در اين سيستم وجـود سـلول هـاى شـوان مسباشـد كـه داراى يتانسيل فراوان براى ترميم مىباشد. در تحقيقات اخير تلاش

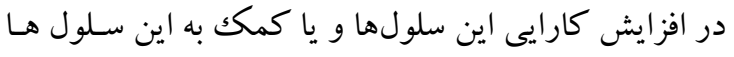
در ترميم عصب مسياشــ. در تحقيـق حاضـر بـا استفاده از

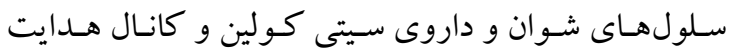
عصب سيليكونى و همجِين روش هاى ايمونوهيستوشيمى و بافتى و الكتروفيزيولوزيكى سعى در ترميم عصب قطع شـده بوده است. در اين تحقيق ديده شد كه استفاده از سلولهـاى شوان و سيتى كولين درون لوله سيليكون موجب ترميم بهتر
باشد كه فاقد سلول شوان مىباشد و به نظر مىرسد به دليـل

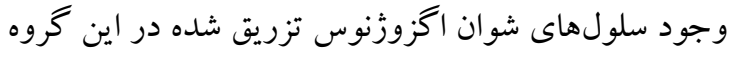
ها باشد. از طرفى استفاده از داروى سيتى كولين نيز موجـب كاهش شكسته شدن غشاى سلولى و توليد اسيدهاى جـرب آزاد و توليدات سمى بافت صدمه ديده مى شـود و همجنسين سيتى كولين موجب ارتقا بقا ويا ترميم نورونهـاى صـدمه ديده مىشود كه بعداز قطع عصب سياتيك ازبيـن رفتـه انــ (YY). اما همانطور كه مشاهده مىشود تاثير سلولهاى شوان در افزايش تعداد اكسـون هـا بيشتر از داروى سـيتى كـولين

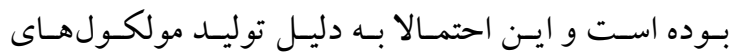

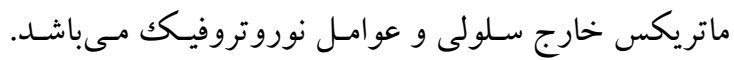
شايد به همين دليل كه هم داروى سيتى كولين و هم سلولهاى شوان موجب بقا نورونى و افزايش ترميم مىشوند است Silicon + Fibrin + Schwann + كه در گرووه تعداد اكسون بيشترى در عصبب ترميم شـده Citicoline وجود دارد و احتمالا اين دو اثر تقـويتى بـر روى يكـديخر دارند. ييوند سـلول هـاى شـوان در محـل ضـايعه عصـب سياتيكك

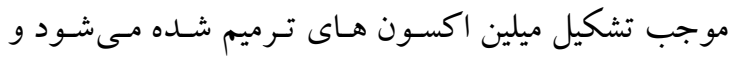
موجب تشكيل نواحى گره اى جديد كه قادر به بيـان كانـال

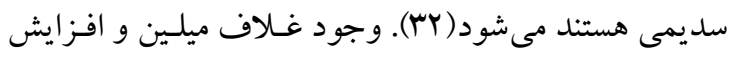

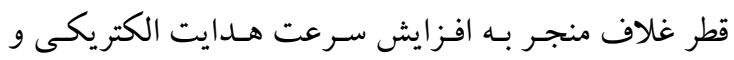

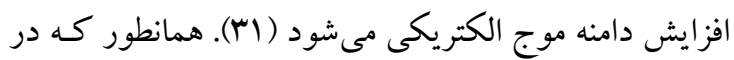

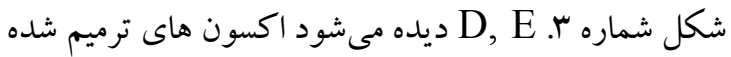
داراى غلاف ميلين ضخيم ترى نسبت به ساير گروه ها هستند

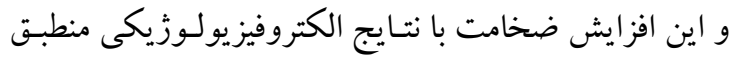

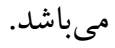
يكى از دلايل استفاده از سيتى كولين در اين طرح اثر ايـن دارو در كاهش توليـد اسـكار بعـد از آسيب عصبى اسـت (YY). در تحقيق حاضر عصب سياتيك به اندازه • ا ميلى متر

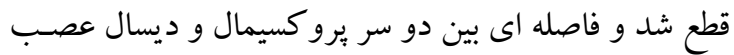
بوجود آمد. در خنين مواردى بخيه زدن دو انتهاى عصـب ليس باعث بوجود آمدن فشار و كشش بر روى عصب مى شود در نتيجه ترميم عصب به خوبى صورت نمى گيرد (ساع) بنابر اين 


$$
\begin{aligned}
& \text { دوره كارشناسى ارشد آناتومى در دانشكده بزشكى دانشكاه } \\
& \text { عصب سياتيك هم از لحاظ بافتى و هم از لحاظ عملكردى } \\
& \text { علوم يزشكى است و نويسند كان مقاله از حمايت هاى بخش إنش } \\
& \text { مى شود. }
\end{aligned}
$$

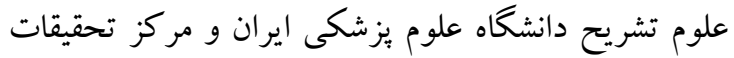

$$
\begin{aligned}
& \text { تقدير و تشكر } \\
& \text { سلول هاى بنيادى سيستم عصبى دانشگاه علوم يزشكى } \\
& \text { سمنان و همجنين مركز تحقيقات جشم فارابى كمال تشكر }
\end{aligned}
$$

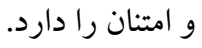

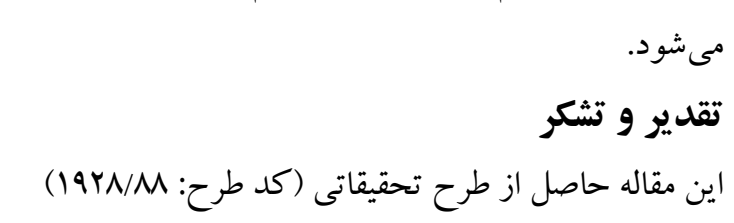

\section{References}

1. Quan D, Bird SJ. Nerve conduction studies and electromyography in the evaluation of peripheral nerve injuries. Univ Pa Orthop J 1999;12:45-51.

2. Samiee F, Zarrindast M-R. Effect of electrical stimulation on motor nerve regeneration in sciatic nerve ligated-mice. Eur J Transl Myo 2017;27:6488

3. Gordon T. Electrical stimulation to enhance axon regeneration after peripheral nerve injuries in animal models and humans. Neurotherapeutics 2016;13:310-295.

4. Kuyucu E, Gümüs B ,Erbas O, Oltulu F, Bora A. Exenatide promotes regeneration of injured rat sciatic nerve. Neural Regen Res 2017;12:637-43.

5. Gramsbergen A, IJkema-Paassen J, Meek M. Sciatic nerve transection in the adult rat: abnormal EMG patterns during locomotion by aberrant innervation of hindleg muscles. Exp Neurol 2000;161:183-93.

6. Siemionow M, Brzezicki G. Current techniques and concepts in peripheral nerve repair. Int Rev Neurobiol 2009;87:141-72

7. Tan C, Ng MH ,Ohnmar H, Lokanathan Y, Nur-Hidayah H, Roohi S, et al. Sciatic nerve repair with tissue engineered nerve: Olfactory ensheathing cells seeded poly (lactic-coglygolic acid) conduit in an animal model. Indian J Orthop 2013;47:547-522.

8. Johnson P, Wood M, Moore A, Mackinnon S. Tissue engineered constructs for peripheral nerve surgery. Eur Surg 2013;45:122-35.

9. Georgiou M, Bunting SC, Davies HA, Loughlin AJ, Golding JP, Phillips JB. Engineered neural tissue for peripheral nerve repair. Biomaterials 2013;34:7335-43.

10. Belanger K, Dinis TM, Taourirt S, Vidal G, Kaplan DL, Egles C. Recent strategies in tissue engineering for guided peripheral nerve regeneration. Macromol Biosc 2016;16:47281.

11. Jiang L, Jones S, Jia X. Stem cell transplantation for peripheral nerve regeneration: Current options and opportunities. Int J Mol Sci 2017;18:94.

12. Phinney DG, Prockop DJ. Concise review: mesenchymal stem/multipotent stromal cells: the state of transdifferentiation and modes of tissue repair-current views. Stem Cells 2007;25:2896-902.

13. Cooney DS, Wimmers EG, Ibrahim Z, Grahammer J, Christensen JM, Brat GA, et al. Mesenchymal stem cells enhance nerve regeneration in a rat sciatic nerve repair and hindlimb transplant model. Scie Rep 2016;6:31306.

14. Masgutov R, Masgutova G, Mukhametova L, Garanina E, Arkhipova SS, Zakirova E, et al. Allogenic Adipose Derived Stem Cells Transplantation Improved Sciatic Nerve Regeneration in Rats: Autologous Nerve Graft Model. Front Pharmacol 2018;9:86.

15. Ma Y, Ge S, Zhang J, Zhou D, Li L, Wang X, et al. Mesenchymal stem cell-derived extracellular vesicles promote nerve regeneration after sciatic nerve crush injury in rats. Int $J$ Clin Exp Pathol 2017;10:10032-9. 
16. Sinir SSSHM, ve Fonksiyonel R. Investigation of the dose-dependency of citicoline effects on nerve regeneration and functional recovery in a rat model of sciatic nerve injury. Turk Neurosurg 2014;24:54-62.

17. Emril DR, Wibowo S, Meliala L, Susilowati R. Cytidine 'o-diphosphocholine administration prevents peripheral neuropathic pain after sciatic nerve crush injury in rats. $\mathrm{J}$ Pain Res 2016;23:287-91.

18. Wen J, Tan D, Li L, Guo J. Isolation and Purification of Schwann Cells from Spinal Nerves nuof Neonatal Rat. Bio Protocol 2017;7:e2588.

19. Alford EK, Roy RR, Hodgson JA, Edgerton V. Electromyography of rat soleus, medical gastrocnemius, and tibialis anterior during hind limb suspension. Exp Neurol 1987;96:63549.

20. Roganovic Z, Pavlicevic G. Difference in recovery potential of peripheral nerves after graft repairs. Neurosurgery 2006;59:621-33.

21. Nico B, Mangieri D, Benagiano V, Crivellato E, Ribatti D. Nerve growth factor as an angiogenic factor. Microvasc Res 2008;75:135-41.

22. Özay R, Bekar A, Kocaeli H, Karlı N, Filiz G, Ulus İH. Citicoline improves functional recovery, promotes nerve regeneration, and reduces postoperative scarring after peripheral nerve surgery in rats. Surg Neurol 2007;68:615-22.

23. Roozbehi A, Almasi-Tork S, Piryaee A, Sadeghi Y. Effects of cadmium on photoreceptors and ganglionic cells of retinal layer in mice embryo - an ultrastructural study. Indian J Exp Biol 2007;45:469-74.

24. Constantin A-M, Tache S. Stimulating factors for the regeneration of peripheral nerves. Cluj Med 2012;85:9-12.

25. Sheth KA, Iyer CC, Wier CG, Crum AE, Bratasz A, Kolb SJ, et al. Muscle strength and size are associated with motor unit connectivity in aged mice. Neurobiol Aging 2018;128:3667.

26. Chang B, Quan Q, Lu S, Wang Y, Peng J. Molecular mechanisms in the initiation phase of Wallerian degeneration. Eur J Neurosci 2016;44:2040-8.

27. Hsu S-T, Yao C-H, Hsu Y-M, Lin J-H, Chen Y-H, Chen Y-S. Effects of taxol on regeneration in a rat sciatic nerve transection model. Sci Rep 2017;7:45421.

28. Moattari M, Kouchesfehani HM, Kaka G, Sadraie SH, Naghdi M, Mansouri K. Chitosanfilm associated with mesenchymal stem cells enhanced regeneration of peripheral nerves: A rat sciatic nerve model. J Chem Neuroanat 2018;46:54-88.

29. Ayan I, Esenkaya I, Karakaplan M, Germen B, Milcan A, Zorludemir S, et al. The effect of human placental suspension on rat sciatic nerve healing. Acta Orthop Traumatol Turc 2007;41:140-6.

30. Stang F, Keilhoff G, Fansa H. Biocompatibility of different nerve tubes. Materials (Basel) 2009;2:1480-507.

31. Armati P. The function of RhoGTPases in axon ensheathment and myelination: Glia 2008;56:1508-17.

32. Hu X, Hu J, Dai L, Trapp B, Yan R. Axonal and Schwann cell BACE is equally required for remyelination of peripheral nerves. J Neurosci 2015;35:3806-14.

33. Terzis J, Faibisoff B, Williams B. The nerve gap: suture under tension vs. graft. Plast Reconstr Surg 1975;56:166-70. 